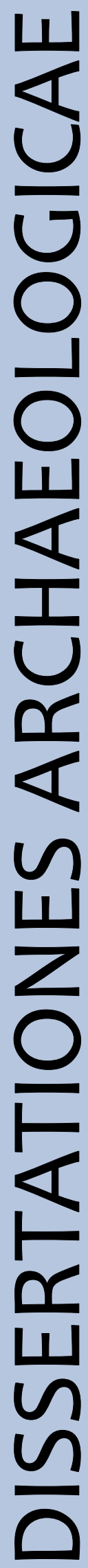

ex Instituto Archaeologico Universitatis de Rolando Eötvös nominatae
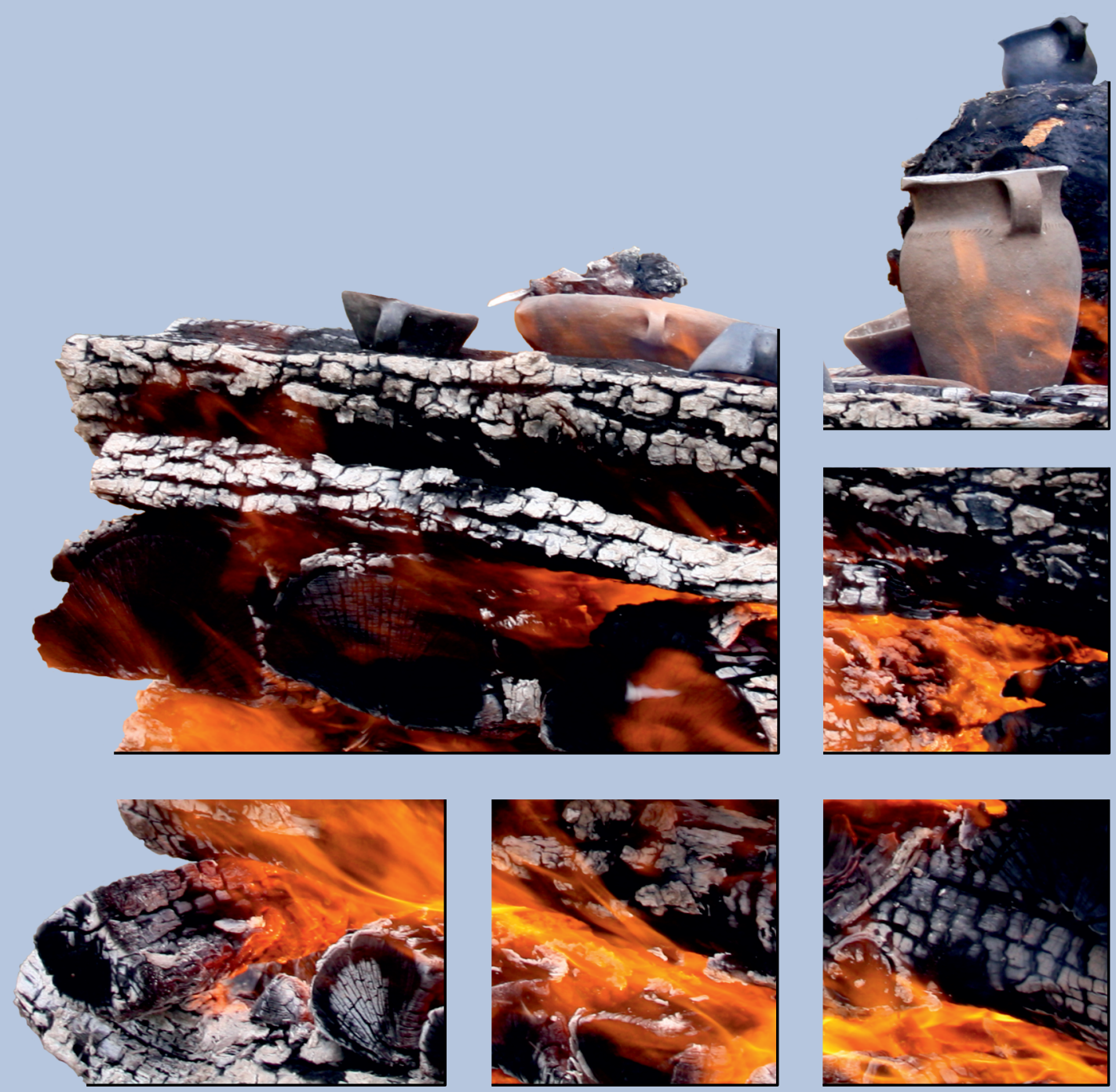

$$
\text { Ser。 3. No } 0_{0} \sigma_{0} \mid 2018
$$




\section{Dissertationes Archaeologicae ex Instituto Archaeologico}

Universitatis de Rolando Eötvös nominatae Ser. 3. No. 6.

Budapest 2018 


\section{Dissertationes Archaeologicae ex Instituto Archaeologico}

Universitatis de Rolando Eötvös nominatae Ser. 3. No. 6.

Editor-in-chief:

DÁvid BARTUS

Editorial board:

LÁsZló BARTOSIEWICZ

LÁSZLÓ BORHY

ZOLTÁN CZAJLIK

ISTVÁN FELD

GÁBOR KALLA

PÁL RACZKY

MiKLÓS SZABÓ

Tivadar Vida

Technical editor:

GÁBOR VÁcZI

Proofreading:

ZsófIA KondÉ

SzILVIA BARTUS-SzÖLLősI

Aviable online at http://dissarch.elte.hu

Contact: dissarch@btk.elte.hu

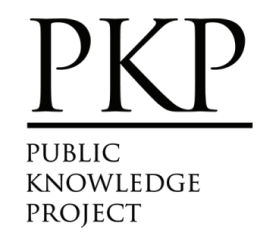

๑ E Eötvös Loránd University, Institute of Archaeological Sciences

Layout and cover design: Gábor Váczi

Budapest 2018 


\section{CONTENTS}

Zsolt Mester

In memoriam facques Tixier (1925-2018)

\section{ARTICLES}

Katalin SEBőK

On the possibilities of interpreting Neolithic pottery - Az újkökori kerámia értelmezési lehetőségeiről

András FüZESI - Pál RACZKY

Öcsöd-Kováshalom. Potscape of a Late Neolithic site in the Tisza region

Katalin SEBőK - Norbert FARAgó

Theory into practice: basic connections and stylistic affiliations of the Late Neolithic settlement at Pusztataskony-Ledence 1

Eszter Solnay

Early Copper Age Graves from Polgár-Nagy-Kasziba

László GuCsi - Nóra Szabó

Examination and possible interpretations of a Middle Bronze Age structured deposition

Kristóf FÜLÖP

Why is it so rare and random to find pyre sites? Two cremation experiments to understand the characteristics of pyre sites and their investigational possibilities

Gábor János TARBAY

"Looted Warriors" from Eastern Europe

Péter MogYoRós

Pre-Scythian burial in Tiszakürt

Szilvia JoHÁczi

A New Method in the Attribution? Attempts of the Employment of Geometric Morphometrics in the Attribution of Late Archaic Attic Lekythoi 
The Roman aqueduct of Brigetio

Lajos JuHÁsz

A republican plated denarius from Aquincum

Barbara HAJDU

Terra sigillata from the territory of the civil town of Brigetio

Krisztina HoppÁL - István VIDA - Shinatria AdHityatAma - Lu Yahui 461

'All that glitters is not Roman'. Roman coins discovered in East Java, Indonesia.

A study on new data with an overview on other coins discovered beyond India

\section{FIELD REPORTS}

Zsolt MESTER - Ferenc CSERPÁK - Norbert FARAGÓ

Preliminary report on the excavation at Andornaktálya-Marinka in 2018

Kristóf FÜLÖP - Denisa M. LÖNHARDT - Nóra SZABÓ - Gábor VÁcZI

Preliminary report on the excavation of the site Tiszakürt-Zsilke-tanya

Bence Simon - Szilvia JohÁcZI - Zita KIS

Short report on a rescue excavation of a prehistoric and Árpádian Age site near Tura

(Pest County, Hungary)

Zoltán CzAJlik - Katalin NovinszKi-Groma - László RupNIK - András BöDőcs - et al. 527

Archaeological investigations on the Süttö plateau in 2018

Dávid BARTus - László BORHY - Szilvia JoHÁczi - Emese SzÁMADó

Short report on the excavations in the legionary fortress of Brigetio (2017-2018)

Bence Simon - Szilvia JoháczI

Short report on the rescue excavations in the Roman Age Barbaricum near Abony

(Pest County, Hungary)

Szabolcs Balázs NAGY

Recent excavations at the medieval castle of Bánd 


\section{Thesis Abstracts}

Rita JENEY

Lost Collection from a Lost River: Interpreting Sir Aurel Stein's "Sarasvatī Tour" in the History of South Asian Archaeology

István VIDA

The Chronology of the Marcomannic-Sarmatian wars. The Danubian wars of Marcus Aurelius in the light of numismatics

Zsófia MASEK

Settlement History of the Middle Tisza Region in the $4^{\text {th }}-6^{\text {th }}$ centuries AD.

According to the Evaluation of the Material from Rákóczifalva-Bagi-földek 5-8-8A sites

Alpár Doвоs

Transformations of the human communities in the eastern part of the Carpathian Basin between the middle of the $5^{\text {th }}$ and $7^{\text {th }}$ century. Row-grave cemeteries in Transylvania, Partium and Banat 


\title{
Early Copper Age Graves from Polgár-Nagy-Kasziba
}

\author{
ESZTER SOLNAY \\ Institute of Archaeological Sciences \\ Eötvös Loránd University \\ eszter.solnay@gmail.com
}

\begin{abstract}
Four Early Copper Age graves were excavated at Polgár-Nagy-Kasziba; two young children, and two adults - the latter including an elderly man and a woman. They all belong to the so-called Tiszapolgár culture. Thanks to numerous examinations - meaning anthropology, pathology or AMS dating -, much information were revealed about the four individuals, but they were never completely published. This paper analyses in details the whole grave cluster compared to the other graves from the Tiszapolgár culture, especially at the Polgár region. As a result, the personal biographies of the four individuals were created. However, it seems that all the four deceased were connected to high prestige in some way because of their age, gender, kinship or personal achievements.
\end{abstract}

\section{Introduction}

In this article, I present the Early Copper Age graves from Polgár-Nagy-Kasziba excavated in 1996 during the rescue excavation on the motorway M3. They were presented in the "Path into the Past" exhibition in 1997, and shortly published by Pál Raczky and his colleagues in the catalogue of the exhibition. ${ }^{1}$ However, until now, they were never completely published.

\section{The site}

Polgár-Nagy-Kasziba (i. e. Polgár Site no. 12) is located in the northern part of the Great Hungarian Plain, the northeastern side of the so-called Polgár Island (Fig. 1), next to the former Király Brook. The brook and the area is well visible on the map of the Second Military Survey (Fig. 2). The four Early Copper Age graves were found in the northern border of the excavation field (Figs. 3, 4), however, no traces of a Copper Age settlement were found. According to Zsuzsanna Siklósi and Márton Szilágyi, the Early Copper Age graves can be dated between $4450-4350 \mathrm{cal} \mathrm{BC} .^{2}$

The Polgár Island was inhabited intensively during the Neolithic and the Copper Age; several Linear Pottery culture settlements and four large Late Neolithic settlement complexes are known; Polgár-Csőszhalom, Polgár-Bosnyákdomb, Polgár-Cibó-hát and Polgár-Kígyósdomb. ${ }^{3}$ Polgár-Csőszhalom was abandoned around 4516 (68.2\%) 4455 cal BC and Polgár-Bosnyákdomb around 4525 (68.2\%) $4470 \mathrm{cal} \mathrm{BC},{ }^{4}$ which means the beginning of the Early Copper

RACZKY et al. 1997.

SiKLÓsi - SzILÁgyi 2016, 68, Fig. 1.

RACZKY et al. 2014, 323.

RACZKy - ANDERs 2016, 116. 
Age in the region. ${ }^{5}$ During the Early and Middle Copper Age, numerous small, satellite settlements appeared in the region; Pál Raczky, Alexandra Anders, and Zsuzsanna Siklósi could collect 24 sites (settlements, cemeteries and grave clusters). ${ }^{6}$ Among them, the best-researched site is Tiszapolgár-Basatanya ${ }^{7}$ in the northern side of the region.

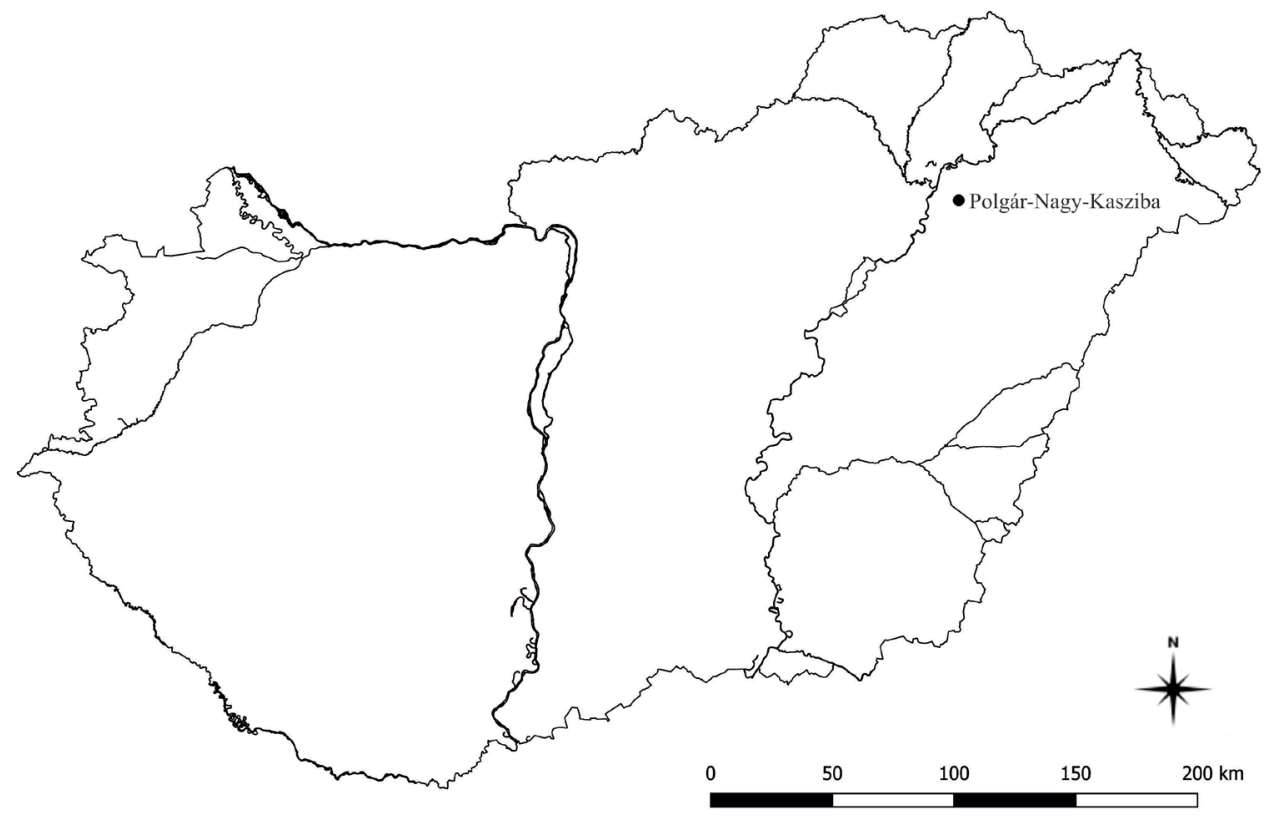

Fig. 1. Location of Polgár-Nagy-Kasziba.

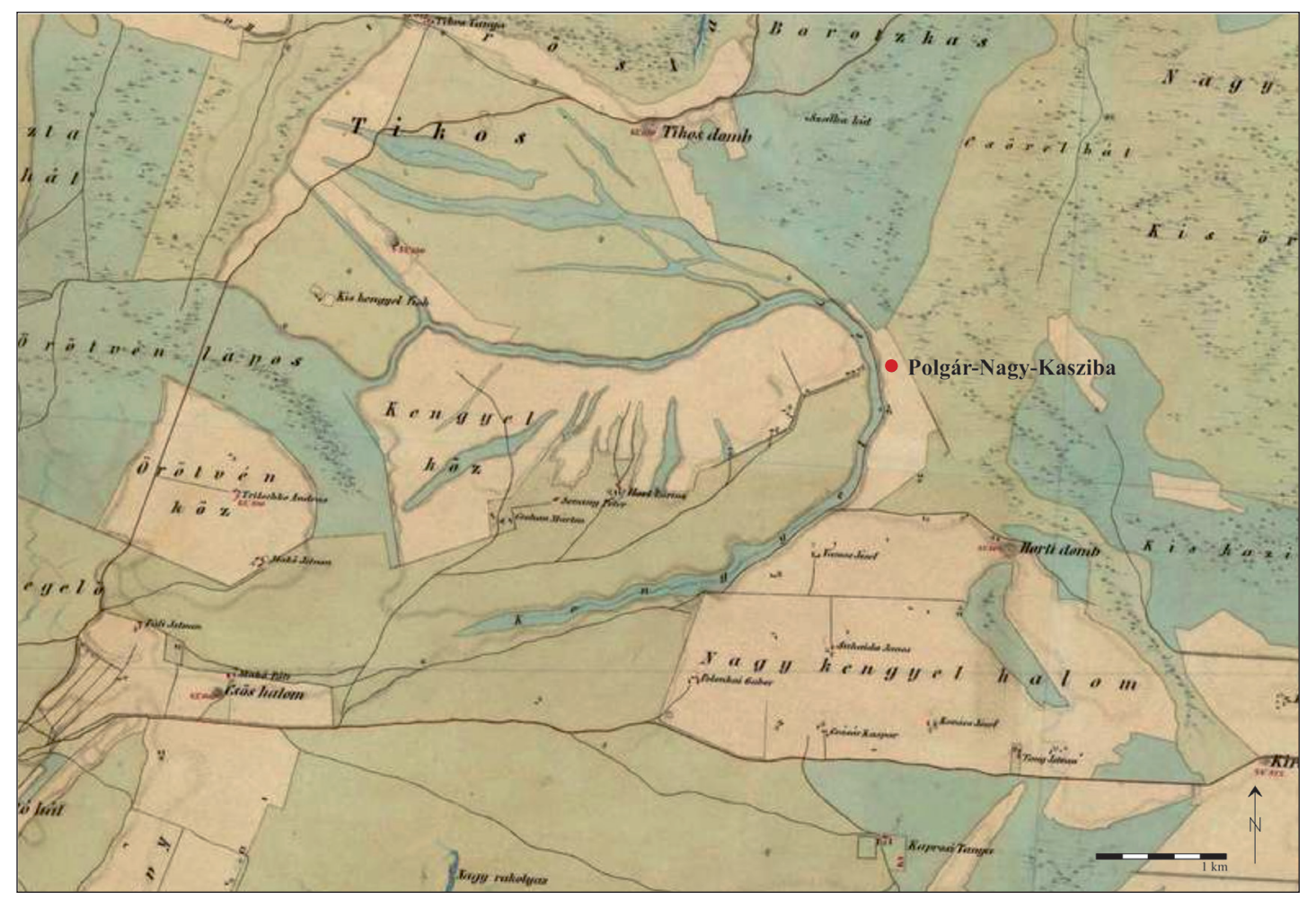

Fig. 2. Polgár-Nagy-Kasziba on the map of the Second Military Survey.

5 SiKLÓSI - SZILÁGYI 2016, 67.

6 RAcZKy et al. 2014, 323, Fig. 4.

7 BognÁr-KutZián 1963. 

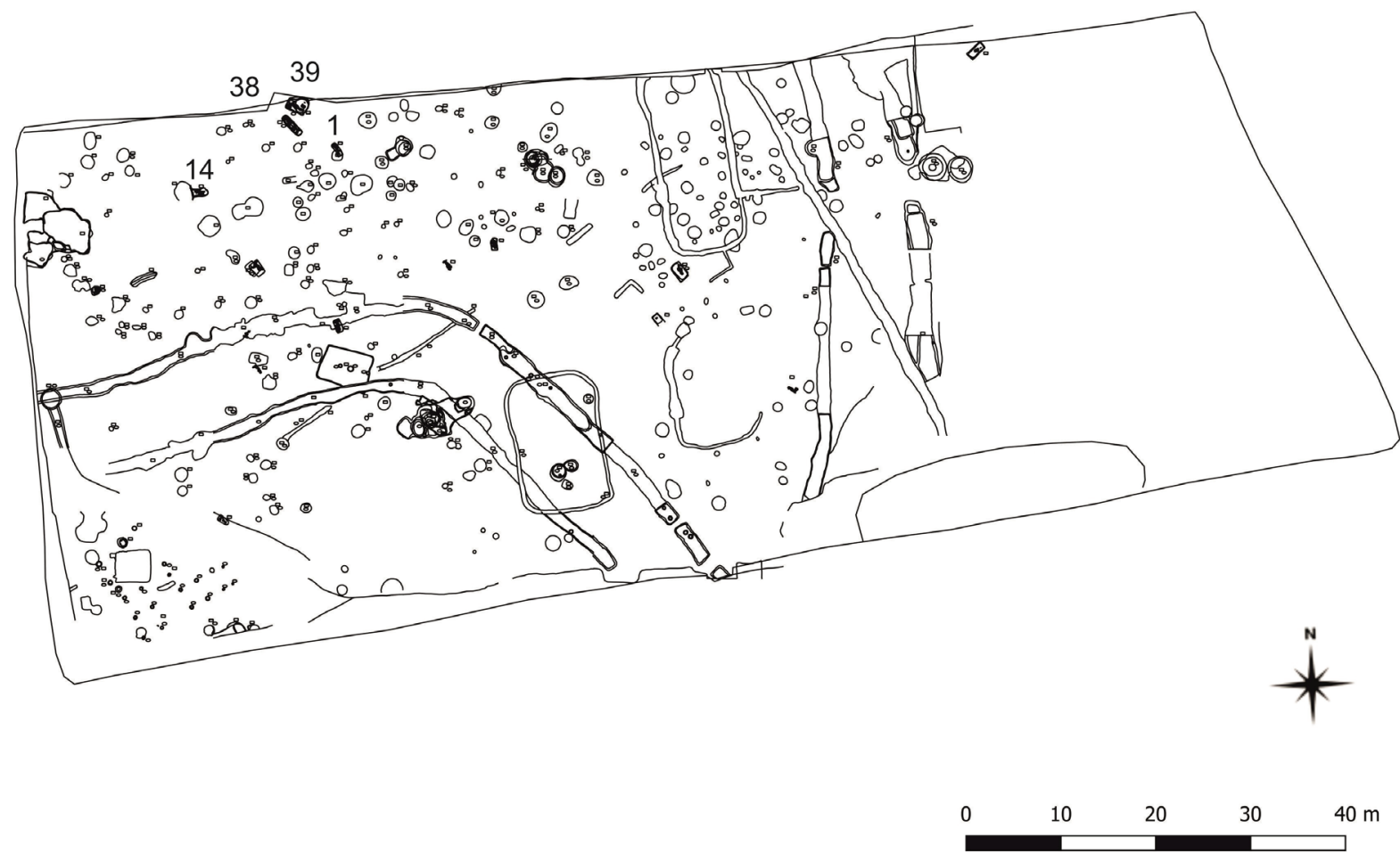

Fig. 3. The excavation map of the site.

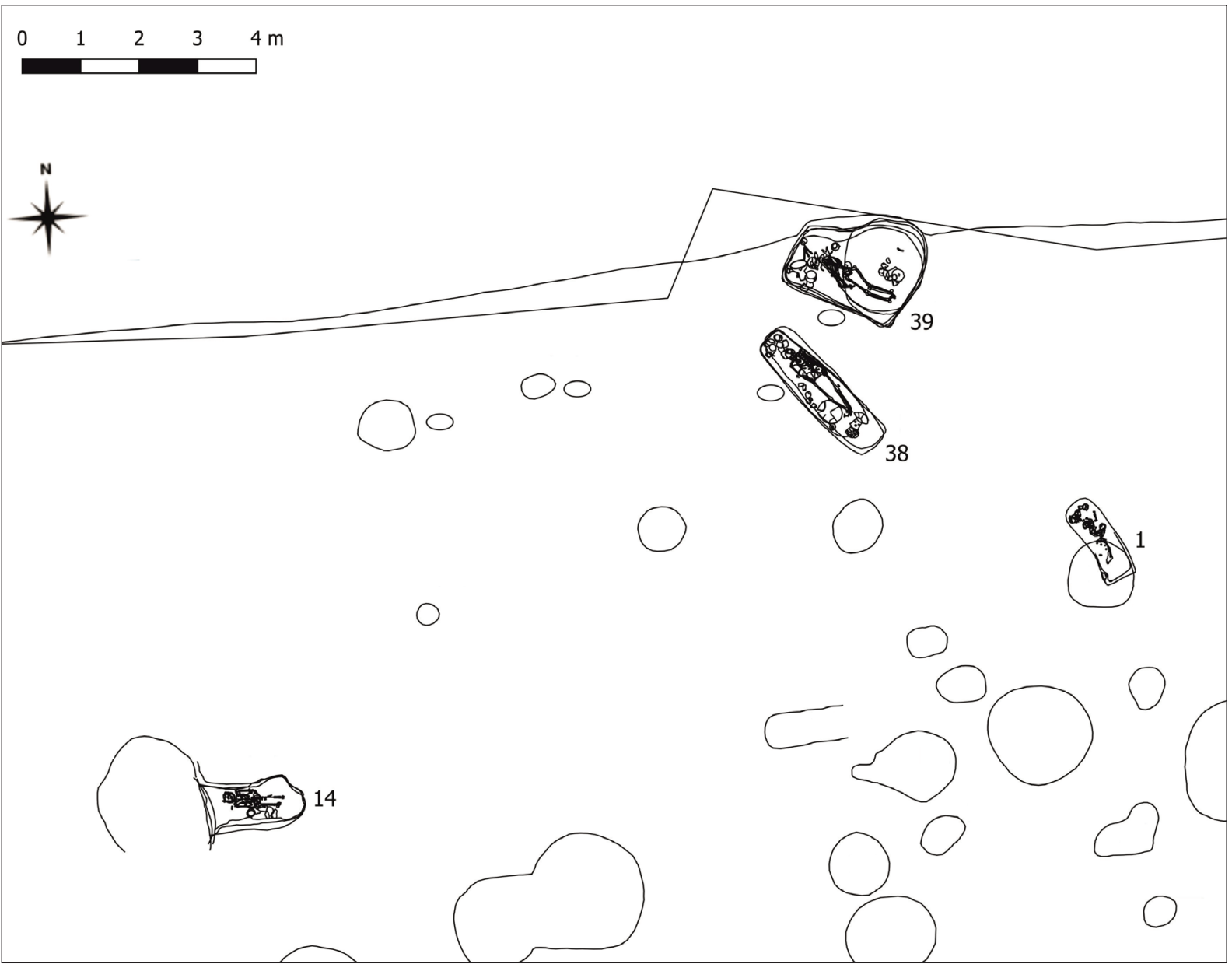

Fig. 4. Position of the Early Copper Age graves. 


\section{The graves}

Grave 1 (Fig. 5)

The grave pit has a rounded oblong shape, it was $3 \mathrm{~m}$ long and $1.1 \mathrm{~m}$ wide. The orientation of the pit and the skeleton was northwest-southeast. The grave was slightly disturbed, the skull was found in the northwestern part of the pit. The skeleton belongs to a 3-4-year-old child. ${ }^{8}$ The two humeri laid left of the skull. The mandible and some ribs were found in the middle of the grave, south of the skull. The legs situated on the SE side of the grave. From the position of the arms and legs, we can assume that the deceased laid on the left side in a contracted position.

Grave goods:

1. Hollow-pedestalled goblet (Fig. 10.1) was found next to Grave good 2, E of the skull. The outer and inner surfaces burned out in light brown. It has a thick, smoothed wall and it is tempered with sand and grog. The rim of the goblet is sharply everted, the pro-

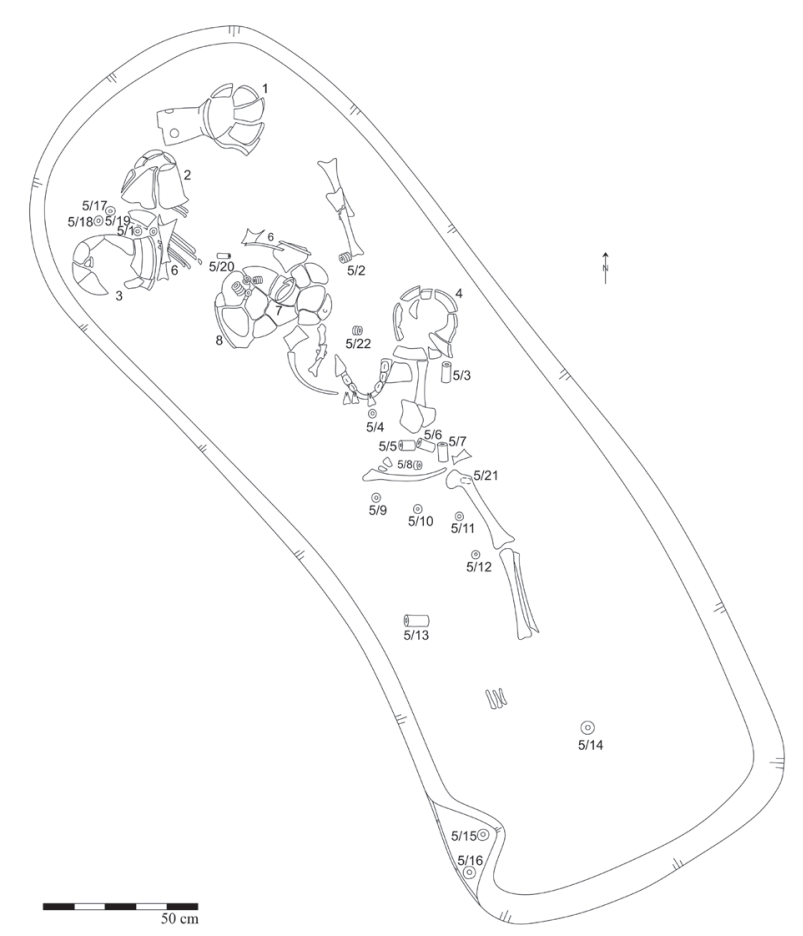

Fig. 5. Grave 1. file is biconical, and the bottom is sharply fractured in the joining. The hollow-pedestal is conical, with three rounded holes on the lower part of the vessel. Two large pointed lugs decorate the goblet. Bognár-Kutzián period I, variant I2. ${ }^{9}$ H.: $14.8 \mathrm{~cm}$; Rd.: $10.4 \mathrm{~cm}$; Pd.: $6.3 \mathrm{~cm} .{ }^{10}$

2. Tumbler (Fig. 10.2) was found between Grave goods 1 and 3, E of the skull. The inner surface burned out grey, the inner surface burned out partly orange, partly light grey. It has a thin, smoothed wall and it is tempered with sand. It has a sharply everted rim, conical profile, flat base. Four rounded lugs decorate the vessel. Bognár-Kutzián period I, variant A2. ${ }^{11} \mathrm{H} .: 6.3 \mathrm{~cm}$; Rd.: $9.7 \mathrm{~cm}$; Bd.: $6.3 \mathrm{~cm}$.

3. Tumbler (Fig. 11.1) was found next to Grave good 2, E of the skull. The outer and inner surfaces burned out dark grey. It has a thin, smoothed wall and it is tempered with sand and grog. It has a slightly everted rim, S-shape profile, flat base. Two horizontally perforated, rounded lugs decorate the upper part of the vessel, and four horizontally perforated, pointed lugs decorate the lower part of the tumbler. Bognár-Kutzián period I, variant A1. ${ }^{12} \mathrm{Rd} .: 10 \mathrm{~cm}$; Bd.: $5 \mathrm{~cm}$.

4. Tumbler (Fig. 11.2) was found next to the $\mathrm{N}$ wall of the pit, near the child's mandible. The outer and inner surfaces burned out dark grey. It has a thin, smoothed wall and tempered with sand and grog. It has a sharply everted rim, conical profile, flat base. Bognár-Kutzián period I, variant A2. ${ }^{13}$ Rd.: $12 \mathrm{~cm}$; Bd.: $3 \mathrm{~cm}$.

5. Beads $^{14}$ (Fig. 12.1)

5/1 - 1 rounded limestone bead was found between Grave goods 2 and 3. D.: $1.7 \mathrm{~cm}$; Th.: $0.77 \mathrm{~cm}$. $5 / 2-4$ rounded limestone beads were found next to Grave good 8. D.: $0.79-0.89 \mathrm{~cm}$; Th.: $0.17-0.3 \mathrm{~cm}$. $5 / 3-1$ rounded limestone bead was found next to Grave good 4. D.: $1.8 \mathrm{~cm}$; Th.: $2.65 \mathrm{~cm}$.

8 K. ZOFFMANN 2004, 86.

9 BognÁR-Kutzián 1972, 126-128; BognÁR-KutZiÁn 1963, 257-258.

10 Abbrevations: $\mathrm{H}=$ high; $\mathrm{Rd}=$ rim diameter; $\mathrm{Bd}=$ base diameter; $\mathrm{Pd}=$ pedestal diameter; $\mathrm{D}=$ diameter; $\mathrm{Th}=$ thickness; $\mathrm{W}$ = width; L = length.

11 Bognár-Kutzián 1972, 119; BognÁr-Kutzián 1963, 236-238.

12 Bognár-Kutzián 1972, 119; BognÁr-Kutzián 1963, 236-238.

13 BognÁR-Kutzián 1972, 119; BognÁr-KutziÁn 1963, 236-238.

14 The material of the beads were defined by Zsuzsanna Tóth. 
5/4 - According to the drawing of the grave, 16 limestone beads were found next to the child's mandible. ${ }^{15}$

5/5 - 1 rounded and 1 oval limestone bead were found in the middle of the grave. rounded: D.: 0.87 cm; Th.: $0.3 \mathrm{~cm}$; oval: D.: $1.21 \mathrm{~cm}$; Th.: $2.34 \mathrm{~cm}$.

5/6 - 1 oval limestone bead was found in the middle of the grave. D.: $1.24 \mathrm{~cm}$; Th.: $2.67 \mathrm{~cm}$.

5/7 - 1 oval limestone bead was found in the middle of the grave. D.: $1.15 \mathrm{~cm}$; Th.: $2.83 \mathrm{~cm}$.

5/8 - 2 rounded limestone beads were found in the middle of the grave. D.: $1.08 \mathrm{~cm}$; Th.: $0.4 \mathrm{~cm}$.

5/9 - 1 rounded limestone bead was found in the middle of the grave. D.: $0.96 \mathrm{~cm}$; Th.: $0.25 \mathrm{~cm}$.

5/10 - 1 rounded limestone bead was found in the middle of the grave. D.: $1 \mathrm{~cm}$; Th.: $0.33 \mathrm{~cm}$.

5/11 - 1 rounded limestone bead was found in the middle of the grave. D.: $0.81 \mathrm{~cm}$; Th.: $0.26 \mathrm{~cm}$.

5/12 - 2 oval limestone beads were found in the middle of the grave. D.: $0.97 \mathrm{~cm}$; Th.: $0.32 \mathrm{~cm}$.

5/13 - 1 oval limestone bead was found between the legs and the SW wall of the pit. D.: $1.13 \mathrm{~cm}$;

Th.: $3.04 \mathrm{~cm}$.

5/14 - 1 rounded limestone bead was found near the SE wall of the grave. D.: $1.09 \mathrm{~cm}$; Th.: $0.68 \mathrm{~cm}$.

5/15 - 1 rounded limestone bead was found in the SW side of the grave. D.: $0.83 \mathrm{~cm}$; Th.: $0.17 \mathrm{~cm}$.

5/16 - 1 rounded limestone bead was found in the SW side of the grave. D.: $0.78 \mathrm{~cm}$; Th.: $0.25 \mathrm{~cm}$.

5/17 - 1 rounded limestone bead was found next to Grave goods 2 and 3. D.: $1.01 \mathrm{~cm}$; Th.: $0.3 \mathrm{~cm}$.

5/18 - 1 rounded limestone bead was found next to Grave goods 2 and 3. D.: $0.92 \mathrm{~cm}$; Th.: $0.2 \mathrm{~cm}$.

5/19 - 1 rounded limestone bead was found next to Grave goods 2 and 3. D.: $0.85 \mathrm{~cm}$; Th.: $0.41 \mathrm{~cm}$.

5/20 - 1 oval limestone bead was found NW from Grave good 8. D.: $1.17 \mathrm{~cm}$; Th.: $2 \mathrm{~cm}$.

$5 / 21$ - According to the drawing of the grave, 1 limestone bead was found under the legs.

$5 / 22$ - According to the drawing of the grave, 4 limestone beads were found next to the skull.

$5 / 23$ - According to the drawing of the grave, 16 limestone beads were found next to the skull.

6. Animal bones were found near the skull, according to the drawing of the grave.

7. Copper bracelet (Fig. 12.2) was found on the skull. Made of thin, wide band, the ends slightly lay on each other. D.: $4.8 \mathrm{~cm}$; W.: $0.8 \mathrm{~cm}$.

Jar (Fig. 11.3) was found near the tomb on the surface.

\section{Grave 14 (Fig. 6)}

The grave pit has a rounded oblong shape, 2.5 $\mathrm{m}$ long and $1.2 \mathrm{~m}$ wide. The orientation of the pit and the skeleton was west-east. The skeleton belongs to a 5-6-year-old child. ${ }^{16}$ The body lay supine in an extended position. The two humeri lay beside the chest and the legs lay beside each other. The eastern wall of the pit was not discernible because it ran over an LBK pit. The skeleton dated to $4340(68.2 \%)$ $4250 \mathrm{cal} \mathrm{BC}$ (Poz-50896 5420 $\pm 40 \mathrm{BP}) .{ }^{17}$

Grave goods:

1. Copper bracelet (Fig. 12. 3) was found on the left humeri. Made of thin, wide band, one of the ends was broken down. D.: $6.1 \mathrm{~cm} ; \mathrm{W} .: 0.5 \mathrm{~cm}$.

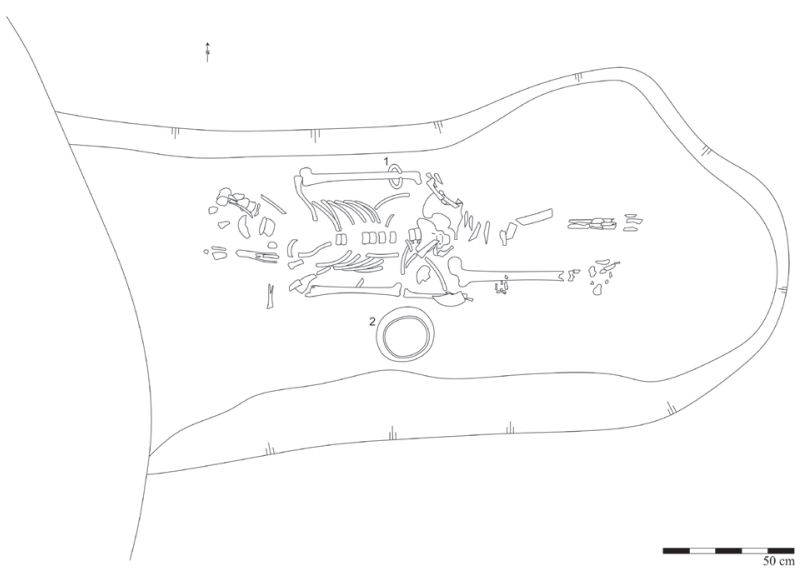

Fig. 6. Grave 14.

2. A large vessel was found near the right elbow, according to the drawing of the grave.

3. Red deer's bones ${ }^{18}$ were found in an unknown position.

15 Note: In the case of missing descriptions and data, the objects were not found during the research.

16 K. ZOFFMANN 2004, 86.

17 SiKLÓsi - SZILÁGYi IN PREP.

18 The animal bones in the graves were examined by Péter Csippán and Anthony Borel. 


\section{Grave 38 (Fig. 7)}

The grave pit has a rounded oblong shape, it is $2.6 \mathrm{~m}$ long, $0.7 \mathrm{~m}$ wide and $12-22 \mathrm{~cm}$ deep. The orientation of the pit and the skeleton was northwest-southeast. The skeleton belongs to a 54-58-year-old woman. The body lay supine in an extended position. The two humeri lay beside the chest and the legs lay beside each other. Dental caries was found on five of her fifteen preserved teeth and other five fell out in her life. Furthermore, cribra orbitalia was observed on both orbital roofs. ${ }^{19}$ The skeleton dated to 4460 (68.2\%) $4360 \mathrm{cal} \mathrm{BC} \mathrm{(Poz-50894} \mathrm{5600 \pm 35} \mathrm{BP).}{ }^{20}$

Grave goods:

1. Beads (Fig. 18. 1)

$1 / 1-32$ rounded limestone beads were found between Grave goods 11 and 14. D.: 0.81$1.1 \mathrm{~cm}$; Th.: $0.23-0.55 \mathrm{~cm}$.

$1 / 2-3$ rounded limestone beads were found near the skull. D.: $0.96-1.03 \mathrm{~cm}$; Th.: $0.3-$

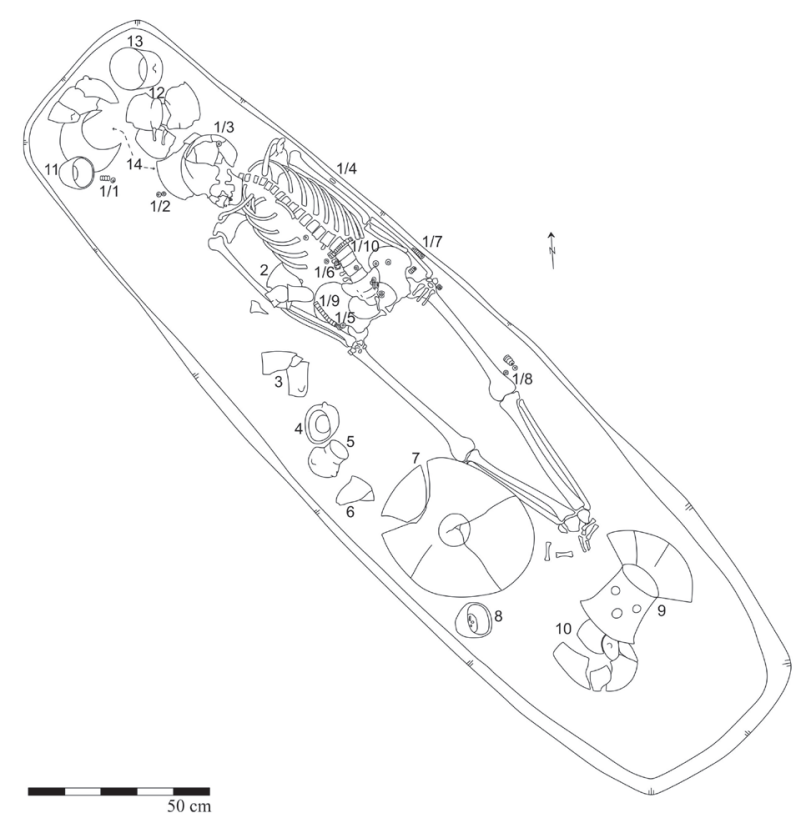

Fig. 7. Grave 38. $0.43 \mathrm{~cm}$.

$1 / 3-1$ rounded limestone bead was found on the skull. D.: $0.8 \mathrm{~cm}$; Th.: $0.25 \mathrm{~cm}$.

$1 / 4-1$ oval limestone bead was found on the skull. D.: $7.3 \mathrm{~cm}$; Th.: $1.14 \mathrm{~cm}$.

$1 / 5-5$ rounded limestone beads were found next to the pelvis, near the beads $1 / 9$. D.: $0.95 \mathrm{~cm}$; Th.: $0.32-0.55 \mathrm{~cm}$.

$1 / 6-10$ rounded limestone beads were found around the spine, near the beads $1 / 10$. D.: $0.85-1 \mathrm{~cm}$; Th.: $0.3-0.42 \mathrm{~cm}$.

$1 / 7-19$ rounded limestone beads were found near the pelvis. D.: $0.97-1.07 \mathrm{~cm}$; Th.: $0.25-0.53 \mathrm{~cm}$. $1 / 8-7$ rounded limestone beads were found next to the left femur. D.: $0.89-0.99 \mathrm{~cm}$; Th.: $0.2-0.52$ $\mathrm{cm}$.

1/9 -20 rounded limestone beads were found near the pelvis. D.: $0.98-1.12 \mathrm{~cm}$; Th.: $0.3-0.52 \mathrm{~cm}$. $1 / 10-25$ rounded limestone beads were found on the spine. D.: $0.94-0.98 \mathrm{~cm}$; Th.: $0.23-0.56 \mathrm{~cm}$. 1/11 - (Fig. 18.2) 2 rounded limestone beads were found in an unknown position. D.: $1.94 \mathrm{~cm}$; Th.: $0.25-0.36 \mathrm{~cm}$.

2. Tumbler (Fig. 13.1) was found between the right elbow and the ribs. The inner surface burned out grey, the outer surface burned out partly orange, partly light grey. It has a thin, smoothed wall and it is tempered with grog. It has a sharply everted rim, conical profile, flat base. Two horizontally perforated, rounded lugs decorate the upper part of the vessel, and four horizontally perforated, rounded lugs decorate the lower part of the tumbler. Bognár-Kutzián period I, variant A2 ${ }^{21}$ H.: 8.4 cm; Rd.: $9.5 \mathrm{~cm}$; Bd.: $8.4 \mathrm{~cm}$.

3. A minor vessel was found near the right forearm, according to the drawing of the grave.

4. Tumbler (Fig. 13.2) was found next to the SW wall of the pit, between Grave goods 5 and 6. The outer and inner surfaces burned out dark grey. It has a thin, smoothed wall and it is tempered with sand and grog. It has a slightly everted rim, S-shape profile, flat base. Four horizontally perforated, rounded lugs decorate the lower part of the tumbler. Bognár-Kutzián period I, variant A1.$^{22}$ H.: 9.8 cm; Rd.: $10 \mathrm{~cm}$; Bd.: $4 \mathrm{~cm}$.

5. Jar (Fig. 13.3) was found next to the SW wall of the pit, between Grave goods 4 and 6. The inner surface burned out brownish grey, the outer surface burned out partly orange, partly brownish grey. 
It has a thin, smoothed wall and it is tempered with sand. It has a slightly everted rim, cylindrical neck, sharply fractured between the neck and the shoulder, rounded belly, flat base. Two horizontally perforated, pointed lugs decorate the shoulder and four double lugs decorate the belly. Bognár-Kutzián period I, variant E1. ${ }^{23}$ H.: $9.5 \mathrm{~cm}$; Rd.: $6.9 \mathrm{~cm}$; Bd.: $9.5 \mathrm{~cm}$.

6. Tumbler (Fig. 14.2) was found next to the SW wall of the pit, between Grave goods 4 and 5. The outer and inner surfaces burned out dark grey. It has a thin, smoothed wall and it is tempered with sand and grog. It has a slightly everted rim, S-shape profile, flat base. Two horizontally perforated, rounded lugs decorate the upper part of the vessel. Two triangle - composed of three incised dots - decorate the middle of the belly. Four horizontally perforated, rounded lugs - with incised dots around each lug - decorate the lower part of the tumbler. Bognár-Kutzián period I, variant A1. ${ }^{24}$ H.: $9.9 \mathrm{~cm}$; Rd.: $8.7 \mathrm{~cm}$; Bd.: $3.5 \mathrm{~cm}$.

7. Bowl (Fig. 14.1) was found next to the right leg. The outer and inner surfaces burned out dark grey, somewhere light brown. It has a thick, smoothed wall and tempered with grog. It has an everted rim, straight, outward widening profile, flat base. Four big, horizontally perforated, pointed lugs decorate the middle of the bowl. Bognár-Kutzián period I, variant K1. ${ }^{25} \mathrm{H} .: 36.6 \mathrm{~cm}$; Rd.: $14.8 \mathrm{~cm}$; Bd.: $12 \mathrm{~cm}$.

8. Cup (Fig. 14.3) was found next to the SW wall of the pit, next to Grave good 7. The outer and inner surfaces burned out light grey. It has a thin, smoothed wall and it is tempered with sand. It has an everted rim, straight, outward widening profile, flat base. Four horizontally perforated, rounded lugs decorate the lower part of the tumbler. Bognár-Kutzián period I, variant L2. Shells were found in the vessel. ${ }^{26} \mathrm{H} .: 9.7 \mathrm{~cm}$; Rd.: $4.8 \mathrm{~cm}$; Bd.: $2.3 \mathrm{~cm}$.

9. Hollow-pedestalled bowl (Fig. 15.1) was found near the legs with Grave good 10. The outer and inner surfaces burned out in light brown. It has a thick, smoothed wall and tempered with grog. The bowl has a sharply everted rim, straight, outward widening profile, flat base. The hollow-pedestal is conical, with four rounded holes on the lower part of the vessel. Four horizontally perforated, pointed lugs decorate the middle of the bowl. Bognár-Kutzián period I, variant H3. ${ }^{27} \mathrm{H} .: 21.9$ m; Rd.: $24.5 \mathrm{~cm}$; Bd.: $15.4 \mathrm{~cm}$.

10. Flowerpot-like vase (Fig. 15.2) was found near the legs with Grave good 9. The inner surface burned out black, the outer surface burned out light grey. It has a thick wall and it is tempered with sand and grog. It has an everted rim, straight profile, flat base. Four pointed lugs - perforated from three sides - decorate the middle of the vessel. Bognár-Kutzián period I, variant C2. Small animal bones were found in the vessel. ${ }^{28} \mathrm{H} .: 14.6 \mathrm{~cm}$; Rd.: $12.7 \mathrm{~cm}$; Bd.: $9.3 \mathrm{~cm}$.

11. Tumbler (Fig. 16.1) was found next to the $\mathrm{W}$ wall of the pit, near Grave good 14 . The inner surface burned out light grey, the outer surface burned out light brown. It has a thin, smoothed wall and it is tempered with sand. It has a slightly everted rim, S-shape profile, flat base. Four horizontally perforated, rounded lugs decorate the lower part of the tumbler. Bognár-Kutzián period I, variant A1. Snails and charcoal were found in the vessel. ${ }^{29} \mathrm{H} .: 7.1 \mathrm{~cm}$; Rd.: $7.3 \mathrm{~cm}$; Bd.: $2.3 \mathrm{~cm}$.

12. Hollow-pedestalled goblet (Fig. 16.2) was found next to the skull. The outer and inner surfaces burned out in yellowish brown. It has a thick, smoothed wall and tempered with sand and grog. The rim of the goblet is sharply everted, the neck is short and sharply fractured between the belly and the neck, the profile is biconical, and the bottom is sharply fractured in the joining. The hollow-pedestal is conical, with four rounded holes on the lower part of the vessel. Two large, horizontally perforated, pointed lugs decorate the upper part of the goblet and four horizontally perforated, pointed lugs decorate the belly of the goblet. Bognár-Kutzián period I, variant $\mathrm{I} 1{ }^{30} \mathrm{H}$.: $20 \mathrm{~cm}$; Rd.: $12.4 \mathrm{~cm}$; Bd.: $9.1 \mathrm{~cm}$. 
13. Jar (Fig. 17.1) was partly found at the W corner of the grave pit, and one sherd was found under the skull. The inner surface burned out light grey, the outer surface burned out light brown. It has a thin, smoothed wall and it is tempered with sand. It has a slightly everted rim, cylindrical neck, sharply fractured between the neck and the shoulder, rounded belly, flat base. Two horizontally perforated, pointed lugs decorate the shoulder and four rounded lugs decorate the belly. Bognár-Kutzián period I, variant E2 ${ }^{31} \mathrm{H} .: 12 \mathrm{~cm}$; Rd.: $12.1 \mathrm{~cm}$; Bd.: $4.2 \mathrm{~cm}$.

14. Hollow-pedestalled globular vessel (Fig. 17.2) was found next to the skull. The outer and inner surfaces burned out in light brown. It has a thick, smoothed wall and it is tempered with grog. The rim of the globular vessel is sharply inverted, the belly is rounded, and the bottom is sharply fractured in the joining. The hollow-pedestal is conical, with four rounded holes on the lower part of the vessel. Four minor, horizontally perforated, oblong-shaped lugs decorate the upper part of the globular vessel and four large, horizontally perforated, oblong-shaped lugs decorate the belly of the globular vessel. This shape does not exist in the typology of Ida Bognár-Kutzián, however the variant $\mathrm{N}^{32}$ is similar to this vessel, except for the hollow-pedestal. H.: $31.8 \mathrm{~cm}$; Rd.: $8.1 \mathrm{~cm}$; Bd.: $18.3 \mathrm{~cm}$.

15. Red deer's and, cattle's bones were found in an unknown position.

\section{Grave 39 (Fig. 8)}

The grave pit has a roughly semicircle shape, $2.2 \mathrm{~m}$ long, the longer wide is $1.6 \mathrm{~m}$ and the shorter wide is $1.1 \mathrm{~m}$. The orientation of the pit and the skeleton was northwest-southeast. The skeleton belongs to a 53-59-year-old man. The deceased lay on the right side in a gently contracted position. The arms lay in front of the chest and the legs lay beside each other. Dental caries was found on two of his twenty-six preserved teeth. Furthermore, spondylosis was found on his vertebra, arthrosis on the femur and the tibia, and a healed fracture of the vicula. ${ }^{33}$ The skeleton dated to $4360(68.2 \%) 4260 \mathrm{cal}$ BC (Poz-50895 5470 40 BP). ${ }^{34}$

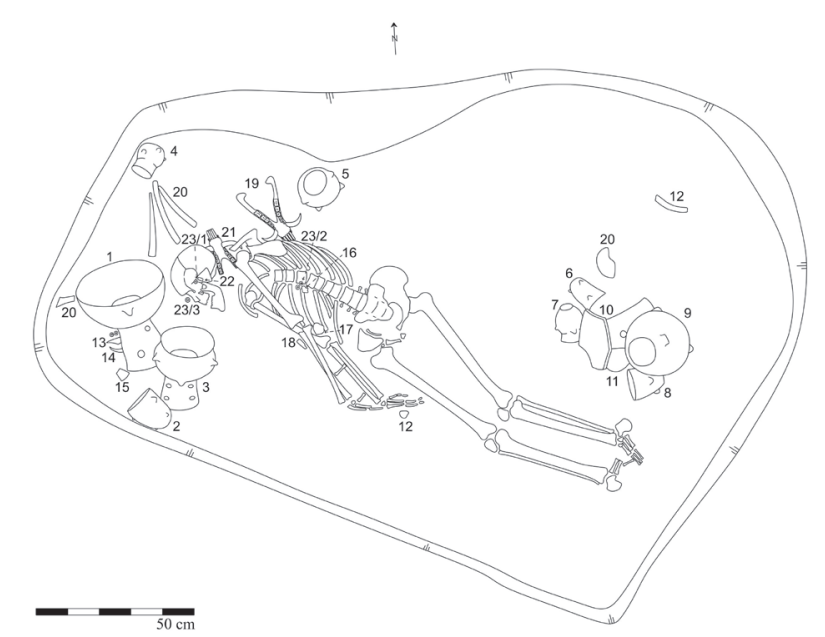

Fig. 8. Grave 39.

Grave goods:

1. Hollow-pedestalled bowl (Fig. 19.1) was found next to the skull with Grave good 2 and 3. The outer and inner surfaces burned out in light brown. It has a thick, smoothed wall and it is tempered with grog. The bowl has a sharply everted rim, straight, outward widening profile, flat base. The hollow-pedestal is conical, with two rounded holes on the lower part of the vessel. Four horizontally perforated, pointed lugs decorate the middle of the bowl. Bognár-Kutzián period I, variant $\mathrm{H} 1{ }^{35}$ H.: $30 \mathrm{~cm}$; Rd.: $29.4 \mathrm{~cm}$; Bd.: $3.6 \mathrm{~cm}$.

2. Tumbler (Fig. 19.2) was found next to the skull between Grave goods 1 and 3. It has a sharply everted rim, conical profile, flat base. Two perforated, pointed lug decorate the upper part and four rounded lugs decorate the lower part of the vessel. Bognár-Kutzián period I, variant A2. ${ }^{36} \mathrm{H}$. : approximately $11-12 \mathrm{~cm}$; Rd.: approximately $9-10.5 \mathrm{~cm}$.

3. Hollow-pedestalled goblet (Fig. 20.1) was found next to the skull with Grave goods 1 and 2. The outer and inner surfaces burned out in light brown and orange. It has a thick, smoothed wall and it is tempered with grog. The rim of the goblet is sharply everted, the neck is short and sharply fractured between the belly and the neck, the profile is biconical, and the bottom is sharply fractured

BognÁR-KutZián 1972, 122-124; BognÁR-KutZiÁn 1963, 244-245.

BognÁr-KutZiÁn 1972, 133.

K. ZOFFMANN 2004, 86.

SiKLÓSI - SZILÁGYI IN PREP.

Bognár-KutZiÁn 1972, 124-126; BognÁr-KutZiÁn 1963, 255-257.

BognÁr-Kutzián 1972, 119; BognÁR-KutZiÁn 1963, 236-238. 
in the joining. The hollow-pedestal is conical, with four rounded holes on the lower part of the vessel. Four horizontally perforated, pointed lugs decorate the shoulder of the goblet and between the lugs, double and triple - triangle formed - incised dots ornamented the vessel. Four horizontally perforated, pointed lugs decorate the belly of the goblet. Bognár-Kutzián period I, variant I1. ${ }^{37}$ H.: $31.6 \mathrm{~cm}$; Rd.: $18.3 \mathrm{~cm}$; Bd.: $12.5 \mathrm{~cm}$.

4. Jar (Fig. 20.2) was found near the ribs in the $\mathrm{N}$ side of the pit. The outer and inner surfaces burned out in light grey. It a has thin, smoothed wall and tempered with sand. It has a slightly everted rim, long, cylindrical neck, sharply fractured between the neck and the shoulder, rounded belly, flat base. Two horizontally perforated, pointed lugs decorate the shoulder and four perforated, pointed lugs decorate the belly. Bognár-Kutzián period I, variant E1 ${ }^{38} \mathrm{H} .: 10.9 \mathrm{~cm}$; Rd.: $6.1 \mathrm{~cm}$; Bd.: $1.9 \mathrm{~cm}$.

5. Jar (Fig. 21.1) was found near the ribs in the $\mathrm{N}$ side of the pit. The outer and inner surfaces burned out in orange and light grey. It has a thin, smoothed wall and tempered with sand and grog. It has a slightly everted rim, long, cylindrical neck, sharply fractured between the neck and the shoulder, rounded belly, flat base. Two horizontally perforated, pointed lugs decorate the shoulder and four perforated, pointed lugs decorate the belly. Bognár-Kutzián period I, variant E1 ${ }^{39} \mathrm{H} .: 12 \mathrm{~cm}$; Rd.: $12.1 \mathrm{~cm}$; Bd.: $3.4 \mathrm{~cm}$.

6. Tumbler (Fig. 21.2) was found next to the $\mathrm{N}$ wall with the Grave goods 7, 8, 9, 10 and 11 . The inner surface burned out light grey, the outer surface burned out light brown. It has a thin, smoothed wall and tempered with grog. It has a slightly everted rim, S-shape profile, flat base. Two horizontally perforated, pointed lugs decorate the upper part and four horizontally perforated, pointed lugs decorate the lower part of the tumbler. Bognár-Kutzián period I, variant A1. ${ }^{40} \mathrm{H} .: 9.5 \mathrm{~cm}$; Bd.: $8 \mathrm{~cm}$; Rd.: $2.4 \mathrm{~cm}$.

7. Jar (Fig. 21.3) was found next to the N wall with Grave goods 6, 8, 9, 10 and 11. The outer and inner surfaces burned out in light brown. It has a thin, smoothed wall and it is tempered with sand and grog. It has a slightly everted rim, cylindrical neck, sharply fractured between the neck and the shoulder, rounded belly, flat base. Two horizontally perforated, pointed lugs decorate the shoulder and four perforated, rounded lugs decorate the belly. Bognár-Kutzián period I, variant E1. ${ }^{41} \mathrm{H} .: 11.4 \mathrm{~cm}$; Bd.: $10.1 \mathrm{~cm}$; Rd.: $4.5 \mathrm{~cm}$.

8. Tumbler (Fig. 22.1) was found next to the $\mathrm{N}$ wall with Grave goods 6, 7, 9, 10 and 11. The outer and inner surfaces burned out in orange. It has a thin, smoothed wall and it is tempered with sand. It has a sharply everted rim, conical profile, flat base. Two horizontally perforated, pointed lugs decorate the upper part, and four horizontally perforated, rounded lugs decorate the lower part of the tumbler. Bognár-Kutzián period I, variant A2. ${ }^{42} \mathrm{H} .: 8.2 \mathrm{~cm}$; Rd.: $9.6 \mathrm{~cm}$; Bd.: $3.3 \mathrm{~cm}$.

9. Jar (Fig. 22.2) was found next to the $\mathrm{N}$ wall with Grave goods 6, 7, 8, 10, 11. The inner surface burned out dark grey, the outer surface burned out light brown. It has a thin, smoothed wall and it is tempered with sand and grog. It has a slightly everted rim, cylindrical neck, sharply fractured between the neck and the shoulder, rounded belly, flat base. Two minor handles decorate the shoulder and four perforated, rounded lugs decorate the belly. Bognár-Kutzián period I, variant E1. ${ }^{43} \mathrm{H} .: 20.7 \mathrm{~cm}$; Rd.: $10 \mathrm{~cm}$; Bd.: $5.1 \mathrm{~cm}$.

10. Hollow-pedestalled vessel (Fig. 23.1) was found next to the $\mathrm{N}$ wall with Grave goods 6, 7, 8, 9 and 11. The outer and inner surfaces burned out in yellowish brown. It has a thick, smoothed wall and it is tempered with sand and grog. The bowl has an outward widening profile, but it fractured and the type cannot be defined. The hollow-pedestal is conical, with three rounded holes on the lower part of the vessel. Four large, horizontally perforated, pointed lugs decorate the bowl. $H .: 12 \mathrm{~cm}$; Rd.: $12.1 \mathrm{~cm}$; Bd.: $15.4 \mathrm{~cm}$. 
11. Tumbler (Fig. 23.2) was found next to the $\mathrm{N}$ wall with Grave goods 6, 7, 8, 9, and10. The outer and inner surfaces burned out in dark grey. It has a thin, smoothed wall and tempered with sand and grog. It has a slightly everted rim, S-shape profile, flat base. Two horizontally perforated, rounded lugs decorate the upper part and four horizontally perforated, rounded lugs decorate the lower part of the tumbler. Bognár-Kutzián period I, variant A1 ${ }^{44} \mathrm{H} .: 11.3 \mathrm{~cm}$; Rd.: $10 \mathrm{~cm}$; Bd.: $3.6 \mathrm{~cm}$.

12. LBK ceramic sherds were found next to the right hand and the $\mathrm{N}$ wall.

13. Antler ${ }^{45}$ (Fig. 24.1) was found next to Grave good 1. It was made of red deer. The entire surface was thickly scraped. It is cone-shaped with a horizontal, hourglass shaped bore-hole. It is in good condition, still usable. H.: $8.8 \mathrm{~cm}$; $\max$ Th.: $1.5 \mathrm{~cm}$; $\max$ W.: $1.5 \mathrm{~cm}$.

14. Wild boar tusk (Fig. 24.2) was found next to Grave good 1. One side is scraped, the other side had become broken before it was placed into the grave. H.: $9.5 \mathrm{~cm}$; max Th.: $2.2 \mathrm{~cm}$; max W.: $1.7 \mathrm{~cm}$.

15. Chise ${ }^{46}$ (Fig. 26.1) was found next to Grave good 1. It was made of polished, fine granulated metamorphic rock. It has a trapezoid form. $2.9 \times 2.9 \times 1.1 \mathrm{~cm}$.

16. Chipped stone (Fig. 26.2) was found between two ribs right of the spine. It is an unretouched mesial fragment of dark obsidian. $1.5 \times 1.5 \times 3 \mathrm{~cm}$.

17. Chipped stone (Fig. 26.3) was found on the right humeri. The flake was made of chocolate flint. $4.4 \times 3.6 \times 0.8 \mathrm{~cm}$.

18. Chipped stone (Fig. 26.4) was found next to the left forearm. It is an unretouched proximal fragment of a flake, which was made of Mezőzombor type limnosilicite. $3.2 \times 1.4 \times 0.4 \mathrm{~cm}$.

19. Swine's mandible (Fig. 25.1) was found left of the chest. It was a hybrid swine - so-called "babos" (spotted) pig - the result of interbreeding between a domestic pig and a wild boar. L: $21.7 \mathrm{~cm}$; W: $9.5 \mathrm{~cm}$.

20. Domestic pig's, red deer's, cattle's bones were found in an unknown position.

21. Domestic pig's mandible (Fig. 25.2) was found between the skull and the neck. She was killed when she was around 26-28 months old. L: $18 \mathrm{~cm}$; W: $8.8 \mathrm{~cm}$.

22. Copper bead (Fig. 26.7) (rounded) was found on the skull. D.: $0.52 \mathrm{~cm}$; Th.: $1.13 \mathrm{~cm}$.

23. Beads

23/1 - 30 rounded limestone beads (Fig. 26.8) were found on the skull. D.: $0.7-0.94 \mathrm{~cm}$; Th.: $0.19-$ $0.48 \mathrm{~cm}$.

23/2 - 5 rounded limestone beads (Fig. 26.9) were found around the upper part of the spine. D.: 0.71-0.8 cm; Th.: $0.14-0.33 \mathrm{~cm}$.

$23 / 3-8$ rounded limestone beads (Fig. 26.10) were found near the skull. D.: $0.78-0.86 \mathrm{~cm}$; Th.: $0.27-0.52 \mathrm{~cm}$.

24. Chipped stone (Fig. 26.6) was found in an unknown position. The flake was made of grey flint. It has a triangle shape, and the base is retouched to a scraper. There is a sickle gloss on the left edge. $3.6 \times 2 \times 0.6 \mathrm{~cm}$.

25. Chipped stone (Fig. 26.5) was found in an unknown position. It is an unretouched mesial fragment of a Wolhynian flint. $2.3 \times 2.1 \times 0.4 \mathrm{~cm}$.

\section{Burial rite}

During the Late Neolithic Tisza-Herpály-Csőszhalom complex on the Great Hungarian Plain, a new burial rite emerged, in which men were buried in right-side position and women buried in left-side position, and generally, both sexes were laid in crouched position. ${ }^{47}$ This practice

BognÁR-KutZiÁn 1972, 119; BognÁR-KutZiÁn 1963, 236-238.

The antler and the wild boar tusk was examined by Zsuzsanna Tóth.

The stone objects were examined by Norbert Faragó.

Anders - NAGY 2007, 88. 
continued in the Early and Middle Copper Age in the so-called Tiszapolgár ${ }^{48}$ and Bodrogkeresztúr ${ }^{49}$ cultures. In the Late Neolithic, this rite occurred frequently, but it only became a rule in the Copper Age. However, other positions can be observed in the Copper Age graves too, for example, extended skeletons are often recorded. ${ }^{50}$

The orientation of the graves can be described similarly. The east-west or southeast-northwest orientations appeared during the Late Neolithic, but merely as a common habit. ${ }^{51}$ It became the rule in the Copper Age, ${ }^{52}$ not only on the Great Hungarian Plain but across Eastern Europe. ${ }^{53}$

The burial rite at Polgár-Nagy-Kasziba is a bit different from the other Tiszapolgár graves but similar to the first period of the Tiszapolgár-Basatanya cemetery where the west-east and northwest-southeast orientation is also general. ${ }^{54}$ Furthermore, Márton Szilágyi mentioned that some of the graves from Polgár-Király-ér-part are directed to northwest-southeast too. ${ }^{55}$ Consequently, this orientation might have been typical in the Polgár region.

The lying of the skeletons at Nagy-Kasziba is slightly different from the general rite of the Early and Middle Copper Age. Three of the four deceased laid in an extended position, two supine (Graves 14, 38) and one on his right side (Grave 39). That is rare, but not unique in the Tiszapolgár culture; for example, this positioning is known from Tiszapolgár-Basatanya ${ }^{56}$, Tiszabábolna ${ }^{57}$ or Szabolcs ${ }^{58}$. If the deceased lay supine it could not be called a gender-specific placing, which is the case in Graves 14 and 38. However, if the skeleton was placed on one of his/her sides - either in extended or crouched position - then it can be gender specified. Therefore, the lying of the man in Grave 39 is male-specific, which was also supported by the anthropological analysis. Moreover, the left side crouched position of the child in Grave 1 suggests that the deceased was a young girl, but in that case, anthropology cannot be used because of the child's young age.

\section{Pathology and teeth}

Zsuzsanna K. Zoffmann performed the anthropological analysis of the graves, ${ }^{59}$ and it is worth discussing the causes that provoked the degenerative deformations in more detail. Unfortunately, the bad preservation of the two children's skeletons could not make it possible to do pathological examinations, so only the two adults will be discussed.

Cribra orbitalia - i. e. the porosity of the orbital roof - could be observed on both orbital roofs of the 54-58-year-old women, ${ }^{60}$ which is a common disease among preindustrial communities. ${ }^{61}$ It was caused by iron deficiency anaemia, which mostly evolved because of the

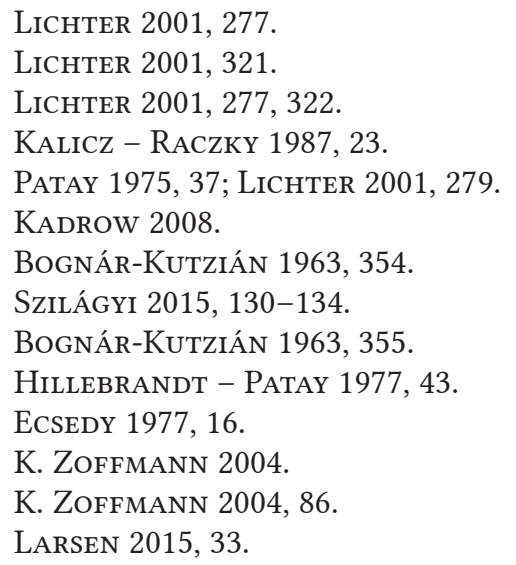


insufficient diet. At that time people consumed a lot of crops - which are rich in phytic acid and carbohydrate -, however, they did not eat enough meat that would have been important due to its protein content. ${ }^{62}$ Defective diet was usually far more frequent among women and children, which can be probably explained by the dietary difference between men and women. ${ }^{63}$ Another common explanation of the cribra orbitalia - besides the genetic disease - is the regular periods and childbirths during which women lost a huge amount of blood ${ }^{64}$ In the case of the 54-58-year-old woman at Polgár-Nagy-Kasziba, both explanations can be expectable. Unfortunately, the skull of the man from Grave 39 was badly preserved and its detailed examination was impossible, so the skulls of the two adults could not be compared.

Arthrosis and spondylosis could be examined on the male skeleton from Grave $39 .{ }^{65}$ Spondylosis is a degenerative pathological condition, the abrasion of the vertebral disk between the vertebras. Although sometimes it has a genetic origin, generally it develops in response to excessive mechanical loads over a period of time. ${ }^{66}$ This can be a link to the other pathological condition of the deceased, the arthrosis of his left femur and tibia. It was observed frequently among preindustrial communities, because they regularly performed intensive physical labour. ${ }^{67}$ The man from Grave 39 might have worked a lot, which caused arthrosis and spondylosis that correlate with his age.

Besides pathology, the condition of the teeth could also be examined. Zsuzsanna Zoffmann observed tooth decay - i. e. dental caries - on 5 cases of the 15 teeth of the woman in Grave 38 , and two, very large holes on the teeth of the man from Grave 39, where caries destroyed

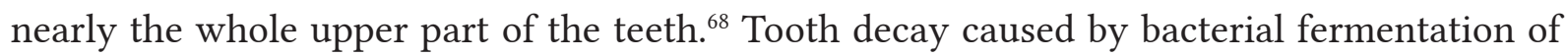
dietary carbohydrates, especially sugars and starches, which is frequent among the settled communities of the Neolithic. ${ }^{69}$ In the case of the Early Copper Age Tiszapolgár culture, it was observed in Bélmegyer-Monoki domb, ${ }^{70}$ Hódmezővásárhely-Elkerülő út Laktanya ${ }^{71}$ and Hódmezővásárhely-Kopáncs-Olasz Sándorné-tanya. ${ }^{72}$ Another dental disease is the loss of teeth, which is observed in the case of the man from Grave $39,{ }^{73}$ and it evolves for similar reasons as dental caries. ${ }^{74}$

\section{Grave goods and animal remains}

Pottery is the most frequent grave good in the Early and Middle Copper Age ${ }^{75}$ which was found in all the four graves at Polgár-Nagy-Kasziba (Fig. 9), altogether 29 pieces. The most common vessel type is tumbler, which represents almost the third of all vessels, and it occurs in three out

LARSEN 2015, 34.

WhitTLE et al. 2013, 79.

WhittLe et al. 2013, 81.

K. ZoFFMANN 2004, 86.

LARSEN 2015, 119.

LARSEN 2015, 194.

K. ZoFFMANN 2004, 86.

LARSEN 2015, 67.

K. ZoFFMANN 2001, 27.

K. ZoFfmann 2004, 85.

K. ZoFFMANN 2004, 86.

K. ZoFFMANN 2004, 86.

LARSEN 2015, 81.

Skomal 1983, 133; Lichter 2001, 280. 
of four graves. Generally small lugs and sometimes incised dots decorate tumblers. The other general type is jar, which appeared only in adults' graves. Besides hollow-pedestalled bowls, these are the most frequent vessels not just at Tiszapolgár-Basatanya, but in the entire Tiszapolgár culture. ${ }^{76}$ Following these, there are three hollow-pedestalled goblets in three graves, and two hollow-pedestalled bowls, which are the most general ceramic types of the first period of Tiszapolgár-Basatanya, ${ }^{77}$ although this vessel type is less frequent in other Tiszapolgár cemeteries. ${ }^{78}$ Besides, a cup, a flowerpot-like vase, a bowl and a hollow-pedestalled globular vessel were found. The last-mentioned type is unknown from Tiszapolgár graves, but the upper part is similar to Bognár-Kutzián's N-type,$^{79}$ which is known from Pusztaistvánháza, ${ }^{80}$ Velké Raškovce, ${ }^{81}$ Tibava $^{82}$ and Lučka, ${ }^{83}$ with the same decorations. Only three of the 29 vessels from Polgár-Nagy-Kasziba were decorated; two tumblers and a hollow-pedestalled goblet.

\begin{tabular}{|l|r|r|r|r|r|}
\hline Ceramic types & Grave 1 & Grave 14 & Grave 38 & Grave 39 & \multicolumn{1}{l|}{ Total } \\
\hline tumbler & 3 & & 4 & 4 & 11 \\
\hline jar & & & 2 & 4 & 6 \\
\hline cup & & & 1 & & 1 \\
\hline flowerpot-like vase & & & 1 & & 1 \\
\hline bowl & & & 1 & & 1 \\
\hline hollow-pedestalled bowl & & & 1 & 1 & 2 \\
\hline hollow-pedestalled goblet & 1 & & 1 & 1 & 3 \\
\hline hollow-pedestalled globular vessel & & & 1 & & 1 \\
\hline hollow-pedestalled vase & & & & & 1 \\
\hline unidentified & & 1 & 1 & & 2 \\
\hline Total & $\mathbf{4}$ & $\mathbf{1}$ & $\mathbf{1 3}$ & $\mathbf{1 1}$ & $\mathbf{2 9}$ \\
\hline
\end{tabular}

Fig. 9. The ceramic types from Polgár-Nagy-Kasziba.

Grave pottery could be related to age and gender. ${ }^{84}$ Generally, the number of vessels in the graves grows with age, but in the case of the right-side crouched skeletons - mostly men they start to decrease around the age of 40 . On the contrary to the other gender that were crouched on the left - mostly women. ${ }^{85}$

At Polgár-Nagy-Kasziba, the situation was very favourable because three copper ornaments were found in three graves - one copper bead and two copper bracelets -, which types were known from many other Tiszapolgár graves. ${ }^{86}$ The form of the two copper bracelets is extremely similar, with their open ends and small size. Usually, the multiple spiral bracelets are the

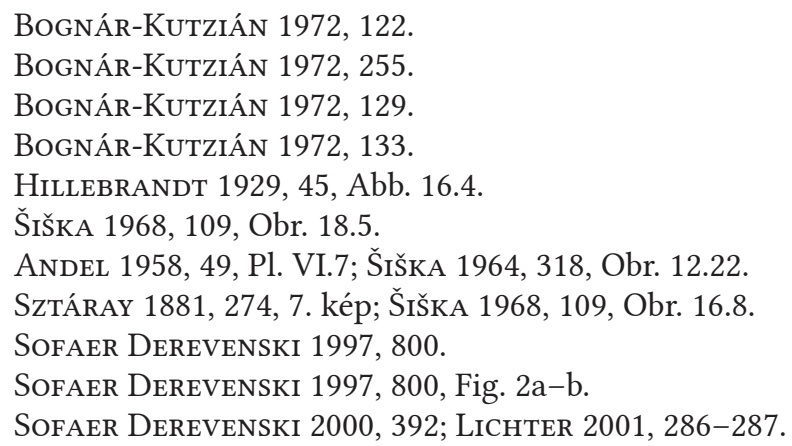


most common - like at Tiszapolgár-Basatanya ${ }^{87}$ - but we find parallels of this form for example from Deszk B, ${ }^{88}$ Hódmezővásárhely-Népkert, ${ }^{89}$ Velké Raškovce ${ }^{90}$ or Tibava. ${ }^{91}$ People generally wore the bracelets in their right arm, near the elbow, however, it was not a strict rule.

Joanna Sofaer observed that the wearing of the copper bracelets is related to age. Some of the infants received this ornament around the age of four - when the community probably recognised them, and they received a social persona ${ }^{92}$ - and they wore it until their mid-twenties - when they stepped into adulthood. ${ }^{93}$ They were constantly set to their size, ${ }^{94}$ which is visible if we compare the size of the two bracelets from Polgár-Nagy-Kasziba. It is a generally accepted theory that copper ornaments in children graves reflect the social position of the parents or the kin. ${ }^{95}$ Another acknowledged fact that not everyone obtained copper. ${ }^{96}$ Therefore, probably only some significant men or families of the community could afford to give copper bracelet to their children, which expresses their wealth or status through this action. ${ }^{97}$

On the contrary, copper beads were found mostly in adult men's graves, generally just a few pieces per graves. ${ }^{98}$ This brings the assumption that they might have a different function than bracelets. Probably they were worn as hair/head-dress or decorated their dress around the pelvis, like at Vésztő-Mágor, ${ }^{99}$ to mark the high status of the owner.

Altogether 240 pieces of limestone beads in three of the four graves were found, ${ }^{100}$ which occurred regularly in the Tiszapolgár graves in various number from some pieces ${ }^{101}$ to hundreds of beads. ${ }^{102}$ Generally, they wore them around their waist, like it was observed on the Late Neolithic Sé-type figurines. ${ }^{103}$ Furthermore, some of them were found on the skull, which they could wear originally in their hair or on their head-dress, as Alexandra Anders and Emese Gyöngyvér Nagy supposed in the case of the Late Neolithic Polgár-Csőszhalom. ${ }^{104}$ At Polgár-Nagy-Kasziba, we could find both types as well as other beads on the chest and near the legs and the arms, which might have been part of the costume too.

Limestone beads occur in mostly female graves and often in children graves, ${ }^{105}$ which was a general trend in the case of the Late Neolithic Spondylus and stone beads too. ${ }^{106}$ However,

87 BognáR-Kutzián 1963, 332.

88 Bognár-Kutzián 1972, Pl. XXXIV.

89 Bognár-Kutzián 1972, Pl. XXXV.

90 VizDAL 1977, Tab. XLI.

91 ŠIŠKA 1964, 333; ŠIŠKA 1968, 155, Obr. 21.

92 Joyce 2000, 477-478; Sofaer Derevenski 2000, 394; Siklósi 2013, 42.

93 Sofaer Derevenski 1997, 882; Sofaer Derevenski 2000, 392.

94 Sofaer Derevenski 2000, 398.

95 McHugh 1999, 24-27.

96 SiKLÓsi 2013, 223.

97 Sofaer Derevenski 2000, 399-400; Siklósi 2013, 122.

98 For example Tiszabábolna (Hillebrandt - PATAy 1977, 4) or Hódmezővásárhely-Népkert (BognÁR-KutziÁN 1972, 45.).

99 HeGEDÜs 1977, 104.

100 The material of the beads were defined by Zsuzsanna Tóth.

101 For example one piece from Abony Site 60.: RajNA 2011, 86.

102 For example 543 pieces from Tiszapolgár-Basatanya: BognáR-Kutzián 1963, 37.

103 P. BARNA 2004, 33.

104 ANDERS - NAGy 2007, 86.

105 Meisenheimer 1989, 50; Sofaer Derevenski 1997, 878; Sofaer Derevenski 2000, 392; Lichter 2001; 286287; RACZKy et al. 2014, 329.

106 SikLósi 2013, 206. 
not only women and children wore them as for instance Polgár-Nagy-Kasziba or Tiszapolgár-Basatanya ${ }^{107}$ presents.

At Polgár-Nagy-Kasziba 6 stone tools were found, all of them in Grave 39; four on the pit floor and two in the fill. ${ }^{108}$ Two tool types can be separated; polished stones and flint flakes. The examination of the raw material is one way of understanding the symbolic meaning of the tools. Although a flake was made of obsidian, it is not possible to tell from which area it derives, because it might originate from the Slovakian Mountains, the Tokaj Mountains ${ }^{109}$ or the Zakarpattia Oblast. ${ }^{110}$ It is certain that it cannot be considered as a long-distance raw material in the Polgár region. ${ }^{111}$ Obsidian was a general raw material in the Early Copper Age, see Tiszapolgár-Basatanya ${ }^{112}$ or Vésztő-Bikeri. ${ }^{113}$ One flake was made of Mezőzombor-type limnosilicite, which occurs in the Tokaj Mountains, ${ }^{114}$ and very popular in the Tiszapolgár culture, ${ }^{115}$ and it also belongs among the local raw materials. However, there is a flake at Polgár-Nagy-Kasziba that was made of Wolhynian flint; a long-distance raw material. This was a very prestigious stone type in the Early Copper Age cemeteries. As an example, it can be found in Grave 1 of Velké Raškovce, ${ }^{116}$ where it was deposited with other valuable objects of copper and gold, expressing the deceased's high status through the old and the new prestige items. ${ }^{117}$ Another long-distance raw material at Polgár-Nagy-Kasziba is the chocolate flint from the Holy Cross Mountains in Poland, ${ }^{118}$ and - unlike the others - it might have been less frequent in the Early Copper Age than in the Late Neolithic ${ }^{119}$ and the Middle Copper Age. ${ }^{120}$ Moreover, sickle gloss could be observed on the left edge of a flake, which means that it had been used before it was deposited into the grave.

Stone tools - polished stones and flint flakes too - generally came from the graves of adult men. ${ }^{121}$ Flint flakes mostly indicate the gender of the deceased, ${ }^{122}$ though the polished stone tools might have expressed status like Middle and Late Neolithic polished stone axes. ${ }^{123}$ Generally, there are only one or two pieces in the graves, and they were found almost exclusively next to the skeletons of men, for instance at Tiszapolgár-Basatanya ${ }^{124}$ or Polgár-Nagy-Kasziba.

There are two kinds of animal remains in the graves of Polgár-Nagy-Kasziba. First, unworked bones, which might be the remains of the food that they placed next to the deceased. Second, a wild boar tusk, a boar mandible and a worked antler known from Grave 39, which probably had a special meaning. The first category applies to all the four graves, and this is a general

107 Sofaer Derevenski 1997, 883, Fig. 3a.

108 The stone objects 16, 18, 24 and 25 were analysed by Norbert Faragó.

109 T. Biró 1998, 70; FARAGó 2015, 53.

110 RÁcz 2013, 132-123; MEster et al. 2012, 280-281.

111 FARAgó 2017, 88, Fig. 2.

112 Cs. BAlogh 2000, 55.

113 GyUCHA - PARKinson 2013, 527-528.

114 T. BIRÓ 1998, 34.

115 BÁCSKAY - T. BIRÓ 2002, 851.

116 VizDAL 1977, 11-17.

117 DzbyŃski 2011, 181.; Lichardus - Lichardus-ItTten 1997, 188; RACZKy et al. 2014, 329.

118 Kaczanowska - KozŁowski 2015, 94.

119 For example at Polgár-Csőszhalom (FArAgó 2017, 87.) or Berettyóújfalu-Herpály (KACzANowsKA - KoZŁOWSKI 2015, 96.).

120 DZByŃsKi 2008, 114-115.

121 Meisenheimer 1989, 39; Sofaer Derevenski 1997, 878; Lichter 2001, 284; Kovács - VÁcZi 2007, 405.

122 Meisenheimer 1989, 49; Sofaer Derevenski 1997, 878; Sofaer Derevenski 2000, 393, Fig. 1.

123 Bently et al. 2012., 9329; Hedges et al. 2013, 368; Siklósi 2013, 192.

124 Sofaer Derevenski 1997, 878, Tab. 2a. 
grave good among the Tiszapolgár and Bodrogkeresztúr culture. ${ }^{125}$ The most frequent animals were domestic pig, cattle and red deer. ${ }^{126}$ Generally, they were found on the pit floor, or sometimes in the vessels like Grave good 10 of Grave 38.

Wild boar tusks and boar mandibles frequently occurred in the Late Neolithic Transdanubia, like Aszód-Papi-földek ${ }^{127}$ and at the Polgár Island too, for example, at Polgár-Csőszhalom. ${ }^{128}$ This tradition lived through to the Early and Middle Copper Age, see for example of Tiszapolgár-Basatanya ${ }^{129}$ or Hajdúböszörmény-Ficsori-tó-dűlő. ${ }^{130}$ Wild boar tusks might have functioned as pendants, ${ }^{131}$ but sometimes they were placed into the graves just because of their symbolic meanings, like at Polgár-Nagy-Kasziba. Boar mandibles might have had a meaning too, however, this partly depends on the type of the boar, because killing a domesticated pig might have been much less tiresome than hunting a wild boar.

Boar mandibles came almost only from male and children graves, and thus they probably reflected the gender. ${ }^{132}$ Wild boar tusks were found merely in adult male graves. ${ }^{133}$ It means that tusks linked to some personal achievement, for example in the field of hunting. ${ }^{134}$

The third unique bone object is the antler from Grave 39. Four similar antler tools are known from the first period of Tiszapolgár-Basatanya, ${ }^{135}$ and further three from settlements and uncertain sites of the Tiszapolgár culture. ${ }^{136}$ Ida Bognár-Kutzián described them as fishing arrowheads. ${ }^{137}$ According to Zsuzsanna Tóth, the piece from Polgár-Nagy-Kasziba could be the head of a composite tool, which was fixed with the aid of two horizontal holes. It was used but it was not in a bad condition, contrary to the broken wild boar tusk from Grave 39.

Generally, an antler of a red deer - irrespectively of whether it was worked or unworked was found in male graves, ${ }^{138}$ and it might have been related to some kind of a personal skill or achievement similarly to wild boar tusks.

\section{Summary}

One of the fundamental tasks when examining burials are the ability to reconstruct some aspects of the deceased's life from the available information, like mobility, health condition, labour, kinship and social persona. ${ }^{139}$ Although the graves from Polgár-Nagy-Kasziba were not the subject of any bioarchaeological research, in my opinion, there is enough information to attempt the reconstruction of their personal biographies.

125 For example: BognÁR-Kutzián 1963, 33-229.

126 The bones were analysed by Anthony Borel and Péter Csippán.

127 SiKLósi 2013, 111.

128 ANDERS - NAgy 2007, 86.

129 BognÁr-KutZiÁn 1963, 310.

130 KovÁcs - VÁczi 2007, 400, Fig. 2.

131 SiKLÓsi 2013, 228.

132 Meisenheimer 1989, 78; Chapman 1997, 141, Tab. 10.3; Sofaer Derevenski 1997, 878; Lichter 2001, 289; RACZKY et al. 2014, 329.

133 Meisenheimer 1989, 44; Chapman 1997, 141, Tab. 10.3; Sofaer Derevenski 1997, 878; Lichter $2001,291$.

134 SiKLÓSI 2013, 229-300.

135 BognÁr-Kutzián 1963, 312.

136 BognÁR-KutZiÁn 1963, 136.

137 BognÁR-KutZián 1963, 136.

138 Chapman 1997, 141, Tab. 10.3; Lichter 2001, 284.

139 Sofaer 2006, 285-286; Zvelebil - Pettitt 2012, 313; Anders 2016a, 1; Anders 2016b, 15-16. 


\section{Individual no. 1}

According to its lying and the several limestone beads, the 3-4-year-old child from Grave 1 was probably a girl, who gained social persona at a young age, because she received a copper bracelet. She might have belonged to a clan or a man who had a high reputation in the community, so they/he could afford to give her a copper ornament.

\section{Individual no. 14}

The lying of the 5-6-year-old child from Grave 14 reflects that the community intended to express an archaeologically undefined aspect of his life, which they judged more important than his gender. At the time of his death, he already owned a social persona, and his male relatives might have been in the same situation in the community as the child's family in Grave 1. It cannot be excluded that they were related in some way.

\section{Individual no. 38}

In the case of this 54-58-year-old woman from Grave 38, the community aimed to express another aspect of her life, not the biological sex, as in the case of the child in Grave 14. However, her gender appeared through several limestone beads. Based on the pottery that was placed next to her, she was a respected member of the community probably partly because of her old age. The cribra orbitalia at both orbital roofs refers to her iron-deficiency probably caused by insufficient diet, menstruation or a large amount of blood loss during childbirths that seem reasonable considering her age. The loss of her teeth and dental caries means that her diet consisted mainly of carbohydrate and sugar. According to the AMS date, she could not be the mother of the child from Grave 14.

\section{Individual no. 39}

The 53-59-year-old man in Grave 39 might have had a high status in his community. This is suggested mostly by his polished stone chisel, which is frequently linked with leading position. His gender is expressed strongly through his lying and the objects in his grave. He probably gained high prestige during his life - for example as a hunter - because he received a wild boar tusk. The copper bead suggests that he distinguished himself with his costume from the other members of the community. He might have performed hard physical labour all his lifetime, which caused the arthrosis and the spondylosis. As the woman from Grave 38, his diet was also rich in carbohydrate and sugar, which is the reason why he had caries too. Based on the AMS date, he could be the father of the child from Grave 14.

\section{Acknowledgement}

I am especially grateful to my supervisor, Zsuzsanna Siklósi for her enormous help and numerous advice. I wish to thank Pál Raczky and Alexandra Anders for generously allowing the publication of the Copper Age assemblage from Polgár-Nagy-Kasziba. I am grateful to Norbert Farago for the analysis of the stone tools, Zsuzsanna Tóth for the analysis of the bone objects, and Péter Csippán and Anthony Borel for the analysis of the animal remains. I would also like to thank Márton Szilágyi for his useful advices and his help in preparing the illustrations. The AMS measurements were financed by the NRDI Fund (NKFI PD 101062, PI: Zsuzsanna Siklósi). 


\section{References}

ANDEL, K. 1958: Pohrebisko z doby medenej v Tibave na východnom Slovensku. Slovenská Archeológia 6, 39-49.

ANDERs, A. 2016a: Csontváztól az emberig. Neolitikus temetkezések kutatásának újabb eredményei Polgár környékén I. Magyar Régészet Online Nyár, 1-6. http://files.archaeolingua.hu/2016NY/ Anders_H16NY.pdf (Last access on 25th January 2019)

Anders, A. 2016b: Újkőkori nőtörténet: bioszociális régészet Polgáron (Neolithic women’s history - biosocial archaeology in Polgár). Tisicum - A Jász-Nagykun-Szolnok megyei múzeumok évkönyve 25, 15-24.

Anders, A. - Nagy, E. Gy. 2007: Late Neolithic burial rites at the site of Polgár-Csőszhalom-dűlő. In: KozŁowski, J. K. - Raczky, P. (eds.): The Lengyel, Polgár and related cultures in the Middle/Late Neolithic in Central Europe. Kraków, 83-96.

BÁcskay, E. - Biró, K. T. 2002: Part IV: Preliminary results from the investigation of the lithic material from the flat settlement. In: Raczky, P. - Meier-Arendt, W. - Anders, A. - Hajdú, Zs. - Nagy, E. Gy. - Kurucz, K. - Domboróczki, L. - Sebők, K. - Sümegi, P. - Magyari, E. -Szántó, Zs. Gulyás, S. - Dobó, K. - Bácskay, E. - Biró, K. T. - Schwartz, C.: Polgár-Csőszhalom (19892000): summary of the Hungarian-German excavations on a Neolithic settlement in eastern Hungary. In: Aslan, R. - Blum, S. - Kastl, G. - Schweizer, F. - Thumm, D. (eds.), Mauerschau: Festschrift für Manfred Korfmann. 2. Remshalden-Grunbach, 833-860.

P. BARNA, J. 2004: Adatok a késő neolitikus viselet megismeréséhez a lengyeli kultúra újabb leletei alapán (Some data to Late Neolithic costume according to new finds of the Lengyel culture). Zalai Múzeum 13, 29-53.

Bentley, R. A. - Bickle, P. - Fibiger, L. - Nowell, G. M. - Dale, C. W. - Hedges, R. E. M. - Hamilton, J. - Wahl, J. - Francken, M. - Grupe, G. - Lenneis, E. - Teschler-Nicola, M. - ARBogast, R.-M. - Hofmann, D. - Whittle, A. 2012: Community differentiation and kinship among Europe's first farmers. Proceedings of the National Academy of Sciences of the United States of America 109/24, 9326-9330.

T. BIRó, K. 1998: Lithic Implements and the Circulation of Raw Materials in the Great Hungarian Plain during the Late Neolithic Period. Budapest.

Bognár-Kutzián, I. 1963: The Copper Age Cemetery of Tiszapolgár-Basatanya. Archaeologia Hungarica 42. Budapest.

Bognár-Kutzián, I. 1972: The Early Copper Age Tiszapolgár Culture in the Carpathian Basin. Archaeologia Hungarica 48. Budapest.

Chapman, J. 1997: Changeing gender relations in the late prehistory of Eastern Hungary. In: Moore, J. - Scott, E. (eds.): Invisible People and Processes. Writing Gender and Childhood into European Archaeology. London, 131-149.

Cs. BAlogh, É. 2000: Rézkori pattintott kőeszközök a Magyar Nemzeti Múzeumban (Copper Age lithics in the Hungarian National Museum). Communicationes Archaeologicae Hungariae, 49-64.

Dzbyński, A. 2008: Rytuat i porozumienie. Racjonalne podstawy komunikacji i wymiany w pradziejach Europy Srodkowej - Ritual and Understanding. Rational Bases of Communication and Exchange in Prehistoric Europe. Rzeszów.

Dzbyński, A. 2011: Mr. Blademan. Macrolithic technology - Eneolithic vocabulary and metaphors. Documenta Praehistorica 38, 173-183.

EcSEDy, I. 1977: Korai rézkori sírok Szabolcsból (Early Copper Age graves from Szabolcs). Folia Archaeologica 28, 11-38.

Faragó, N. 2015: Raw Materials Circulation, Organization of Production and Lithic Technology in the Neolithic/Early Copper Age Transition. In: Hansen, S. - Raczky, P. - Anders, A. - ReingruBER, A. (eds.): Neolithic and Copper Age between the Carpathians and the Aegean Sea. Chronol- 
ogies and Technologies from the 6th to the 4th Millenium BCE. International Workshop Budapest 2012. Archäologie in Eurasien 31. Bonn, 49-56.

FARAGó, N. 2017: Differences in the selection of raw materials at the site of Polgár-Csőszhalom, northeast Hungary. Bulgarian e-fournal of Archaeology 7, 85-115. http://be-ja.org/index.php/Be-JA/ article/view/7 (Last access on 25th January 2019)

Gyucha, A. - Parkonson, W. A. 2013: Archaeological "Cultures" and the Study of Social Interaction: The Emergence of the Early Copper Age Tiszapolgár Culture. In: Anders, A. - Kulcsár, G. (eds.): Moments in Time. Papers Presented to Pál Raczky on His 60th Birthday. Ösrégészeti Tanulmányok - Prehistoric Studies 1. Budapest, 521-538.

Hedges, R. - Bentley, R. A. - Bickle, P. - Cullen, P. - Dale, C. - Fibiger, L -Hamilton, J. - Hofmann, D. - Nowell, G. - Whittle, A. 2013: The supre-regional perspective. In: Bickle, P. Whittle, A. (eds.): The first farmers of central Europe. Diversity in LBK lifeways. Oxford, 343-384.

Hegedüs, K. 1977: A Vésztő-Mágordombi újkőkori és rézkori temetkezések. Bölcsészdoktori értekezés. Budapest.

Hillebrand, J. 1929: A pusztaistvánházi korarézkori temető (Das frühkupferzeitliche Gräberfeld von Pusztaistvánháza). Archaeologia Hungarica 4. Budapest.

Hillebrandt, M. - Patay, P. 1977: Újabb rézkori temetők Dél-Borsodban (Neuere Friedhöfe aus der Kupferzeit in Süd-Borsod). A Herman Ottó Múzeum Évkönyve 16, 43-76.

Joyce, R. A. 2000: Girling the Girl and Boying the Boy. World Archaeology 31, 473-483.

Kalicz, N. - Raczky, P. 1987: Berettyóúffalu-Herpály. In: Raczky, P. (ed.): The Late Neolithic of the Tisza Region. A survey of recent excavations and their findings. Szolnok-Budapest, 105-126.

Kaczanowska, M. - KozŁowski, J. K. 2015: Raw Materials Circulation, Organization of Production and Lithic Technology in the Neolithic/Early Copper Age. In: Hansen, S. - Raczky, P. - Anders, A. Reingruber, A. (eds.): Neolithic and Copper Age between the Carpathians and the Aegean Sea. Chronologies and Technologies from the 6th to the 4th Millenium BCE. International Workshop Budapest 2012. Archäologie in Eurasien 31. Bonn, 93-104.

KADROW, S. 2008: Gender-differentiated burial rites in Europe of the 5th and 4th millennia BC: attempts at traditional archaeological interpretation. Analecta Archaeologica Ressoviensia 3, 49-95.

KovÁcs, K. - VÁczi, G. 2007: The Cemetery of the Early Copper Age Tiszapolgár HajdúböszörményFicsori-tó-dülő. In: KozŁowski, J. K. - Raczky, P. (eds.): The Lengyel, Polgár and related cultures in the Middle/Late Neolithic in Central Europe. Kraków, 397-409.

LARSEN, S. C. 2015: Bioarchaeology. Interpreting Behavior from the Human Skeleton. Cambridge.

Lichardus, J. - Lichardus-Itten, M. 1997: Spätneolithische Funde von Čičarovce (Ostslowakei) und das obere Theißgebiet an der Schwelle zur frühen Kupferzeit. Saarbrücker Studien und Materialen zur Altertumskunde 4/5 (1995-1996), 143-249.

Lichter, C. 2001: Untersuchungen zu den Bestattungssitten des südosteuropäischen Neolithikums und Chalkolithikums. Monographien 5. Mainz am Rhein.

Mchugh, F. 1999: Theoretical and Quantitative Approaches to the Study of Mortuary Practice. British Archaeological Reports - International Series 785. Oxford.

Meisenheimer, M. 1989: Das Totenritual, geprägt durch fenseitsvorstellungen und Gesellschaftsrealität. Theorie des Totenrituals eines kupferzeitlichen Friedhofs zu Tiszapolgár-Basatanya (Ungarn). British Archaeological Reports - International Series 475. Oxford.

Mester, Zs. - FARAgó, N. - Lengyel, Gy. 2012: The lithic raw material sources and interregional human contacts in the northern Carpathian regions: a research program. Anthropologie 50, 275-293.

Patay, P. 1975: Die Bodrogkeresztúr-Kultur. Berlin.

Raczky, P. - Anders, A. 2016: Polgár-Bosnyákdomb, a Late Neolithic tell-like settlement on Polgár Island (NE Hungary). Preliminary results of the investigations. Folia Quaternaria 84, 99-122. http://www.ejournals.eu/FQ/2016/Vol-84/art/8486/ (Last access on 26th January 2019) 
Raczky, P. - Anders, A. - Nagy, E. Gy. - Kriveczky, B. - Hajdú, Zs. - Szalai, T. 1997: Polgár-Nagy Kasziba. Rézkori sírok a Kr. e. V. évezredből - Polgár-Nagy Kasziba. Copper age burials from the last 5th Milennium B.C. In: Raczky, P. - Kovács, T. - Anders, A. (eds.): Utak a múltba - Az M3-as autópálya régészeti leletmentései (Paths into the Past. Rescue excavations on the M3 motorway). Budapest, 47-50.

RACzky, P. - Anders, A. - Siklósi, Zs. 2014: Trajectories of Continuity and Change between the Late Neolithic and the Copper Age in Eastern Hungary. In: Schier, W. - Drasovean, F. (eds.): The Neolithic and Eneolithic in southeast Europe. New approaches to dating and cultural dynamics in the 6th to 4th millenium BC. Prähistorische Archäologie in Südosteuropa 23. Rahden/Westf., 320-346.

RÁcz, B. 2013: Main raw materials of the Palaeolithic in Transcarpathian Ukraine: geological and petrographical overview. In: Mester, Zs. (ed.): The lithic raw material sources and interregional human contacts in the Northern Carpathian regions. Papers for the project funded by the International Visegrad Fund Standart grant n 21110211. Kraków-Budapest, 131-146.

RAJNA, A. 2011: Rézkori temetkezések és kapcsolataik a 4. számú főút Abonyt elkerülő szakaszán. Studia Comitatensia 31, 86-95.

SikLósi, Zs. 2013: Traces of Social Inequality during the Late Neolithic in the Eastern Carpathian Basin. Dissertaiones Pannonicae 4/3. Budapest.

SikLósi, Zs. - SzILÁGYi, M. 2016: Módszertani, interpretációs kérdések az alföldi rézkor radiokarbon keltezése kapcsán (Questions on methodology and interpretation concerning the radiocarbon dating of the Copper Age on the Great Hungarian Plain). Tisicum - A Jász-Nagykun-Szolnok megyei múzeumok évkönyve 25, 65-72.

Siklósi, Zs. - SzILÁGYI, M. In PREP.: Culture, period or style? Re-consideration of Early and Middle Copper Age chronology of the Great Hungarian Plain.

ŠIšKA, S. 1964: Pohrebisko tiszapolgárskej kultúry y Tibave (Gräberfeld der Tiszapolgár-Kultur in Tibava). Slovenská Archeológia 12, 293-356.

ŠIšKA, S. 1968: Tiszapolgárska kultúra na Slovensku (Die Tiszapolgár-Kultur in der Slowakei). Slovenská Archeológia 16, 154-175.

Sкомal, S. N. 1983: Wealth Distribution as a Measure of Prehistoric Change: Chalcolithic to Copper Age Cultures in Hungary. $\mathrm{PhD}$ Dissertation. Los Angeles.

SofAer, J. 2006: The body as material culture: a theoretical osteoarchaeology. Topics in Contemporary Archaeology 4. Cambridge.

Sofaer Derevenski, J. 1997: Age and gender at the site of Tiszapolgár-Basatanya, Hungary. Antiquity. A quarterly review of archaeology 71, 875-890.

Sofaer Derevenski, J. 2000: Rings of life: the role of early metalwork in mediating the gendered life course. World Archaeology 31, 389-406.

SzILÁGyi, M. 2015: Kora rézkori településszerkezet a Közép-Tisza-vidéken. PhD Dissertation. Budapest.

SztÁrAy, A. 1881: Lucskai lelet. Archaeologiai Értesitő 1, 272-275.

VizDAL, J. 1977: Tiszapolgárske pohrebisko vo Vel'kych Raskovciach. Košice.

Whittle, A. - Anders A. - Bentley, R. A. - Bickle, P. - Cramp, L. - Domboróczki, L. - Fibiger, L. - Hamilton, J. - Hedges, R. - Kalicz, N. - Kovács, Zs. E. - Marton, T. - Oross, K. - Pap, I. - Raczky, P. 2013: Hungary. In: Bickle, P. - Whittle, A. (eds.): The first farmers of central Europe. Diversity in LBK lifeways. Oxford, 49-97.

K. Zoffmann, Zs. 2001: Neolitikus és rézkori embertani leletek az Alföldről (Neolithische und kupferzeitliche anthropologische Funde in der Tiefebene). A Móra Ferenc Múzeum Évkönyve - Studia Archaeologica 7, 23-42.

K. Zoffmann, Zs. 2004: Újabb őskori embertani leletek Kelet-Magyarországról (New Prehistoric anthropological finds from East Hungary). A debreceni Déri Múzeum Évkönyve, 83-94. 
Zvelebil, M. - Pettitt, P. 2013: Biosocial archaeology of the Early Neolithic: Synthetic analyses of a human skeletal population from the LBK cemetery of Vedrovice, Czech Republic. Fournal of Anthropological Archaeology 32, 313-329. 


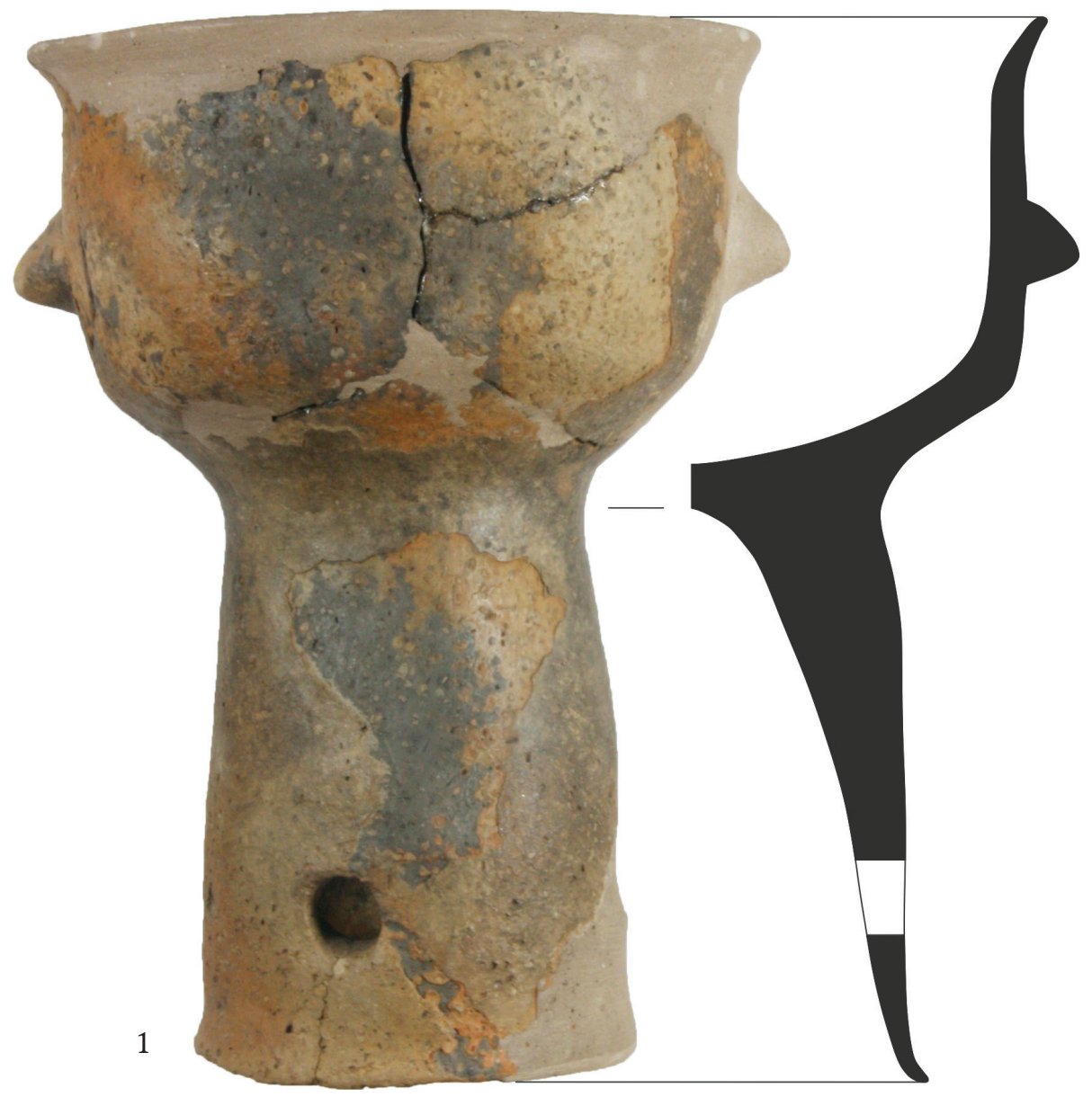

$5 \mathrm{~cm}$

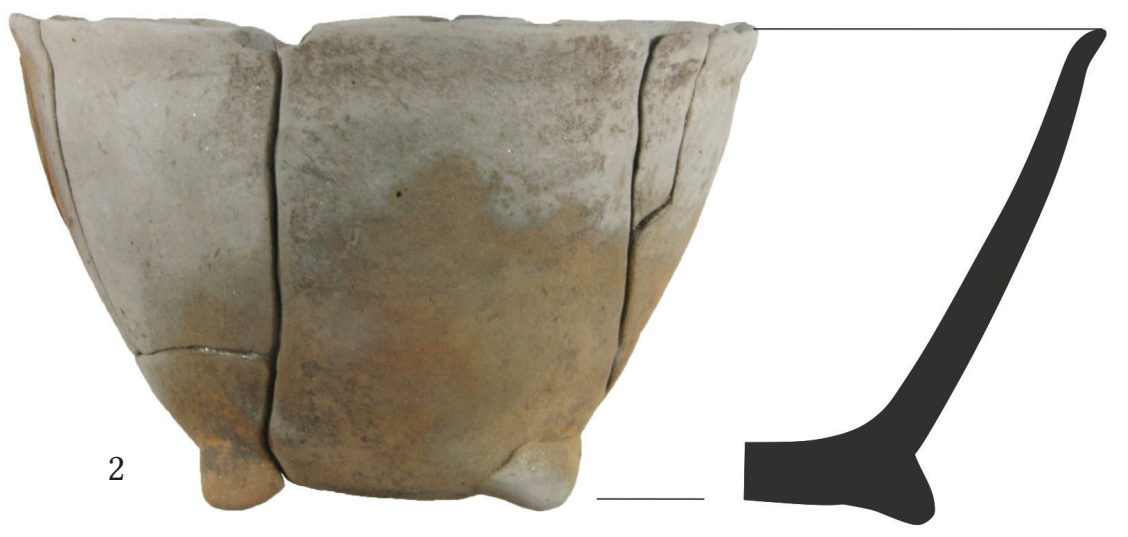

Fig. 10. Grave 1: 1 - hollow-pedestalled goblet, 2 - tumbler. 

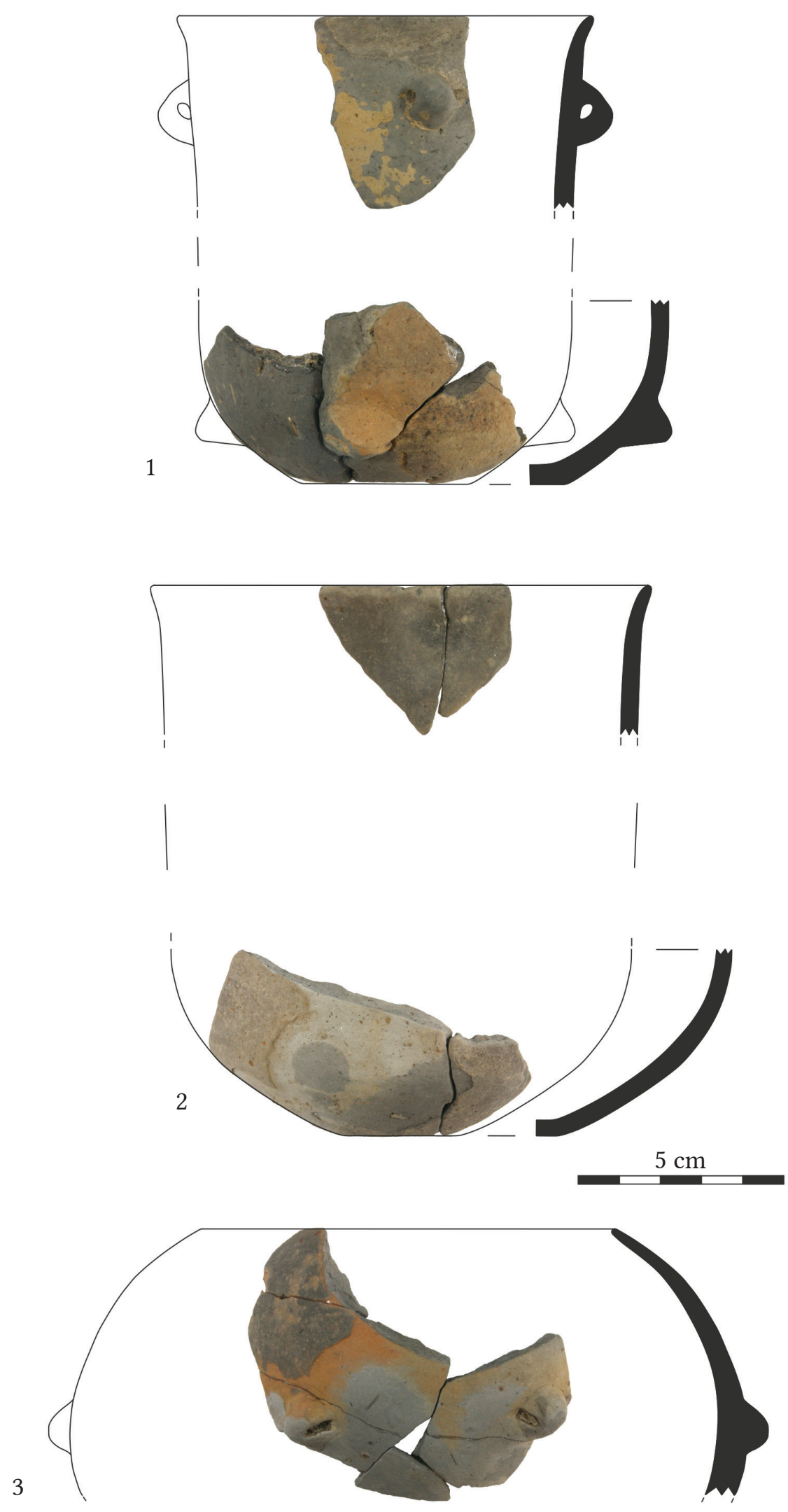

Fig. 11. Grave 1: 1 - tumbler, 2 - tumbler, 3 - jar. 

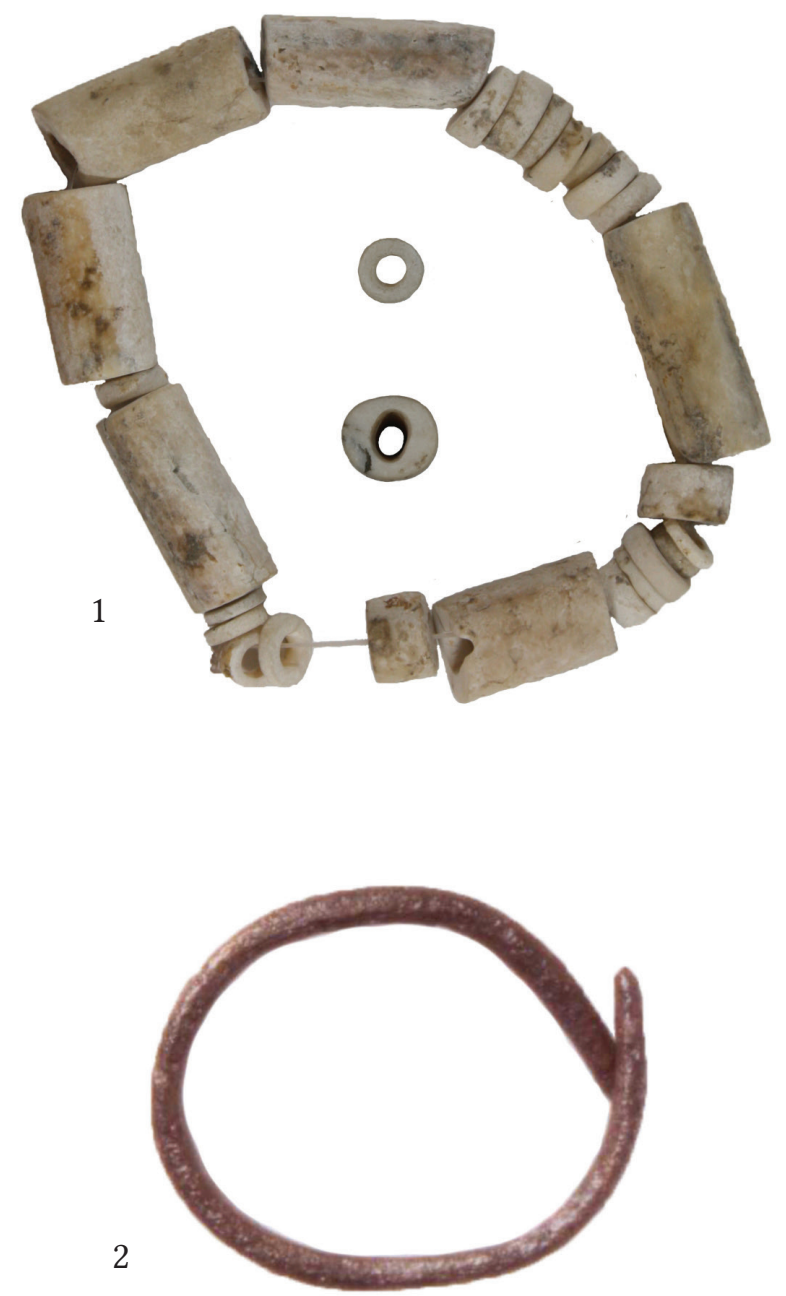

$5 \mathrm{~cm}$
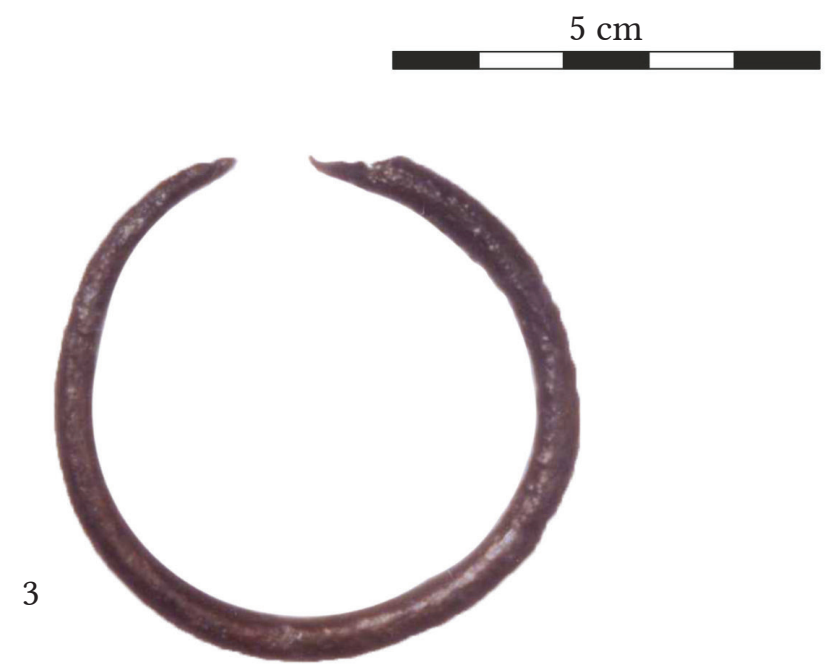

Fig. 12. Grave 1: 1 - beads, 2 - copper bracelet; Grave 14: 3 - copper bracelet. 

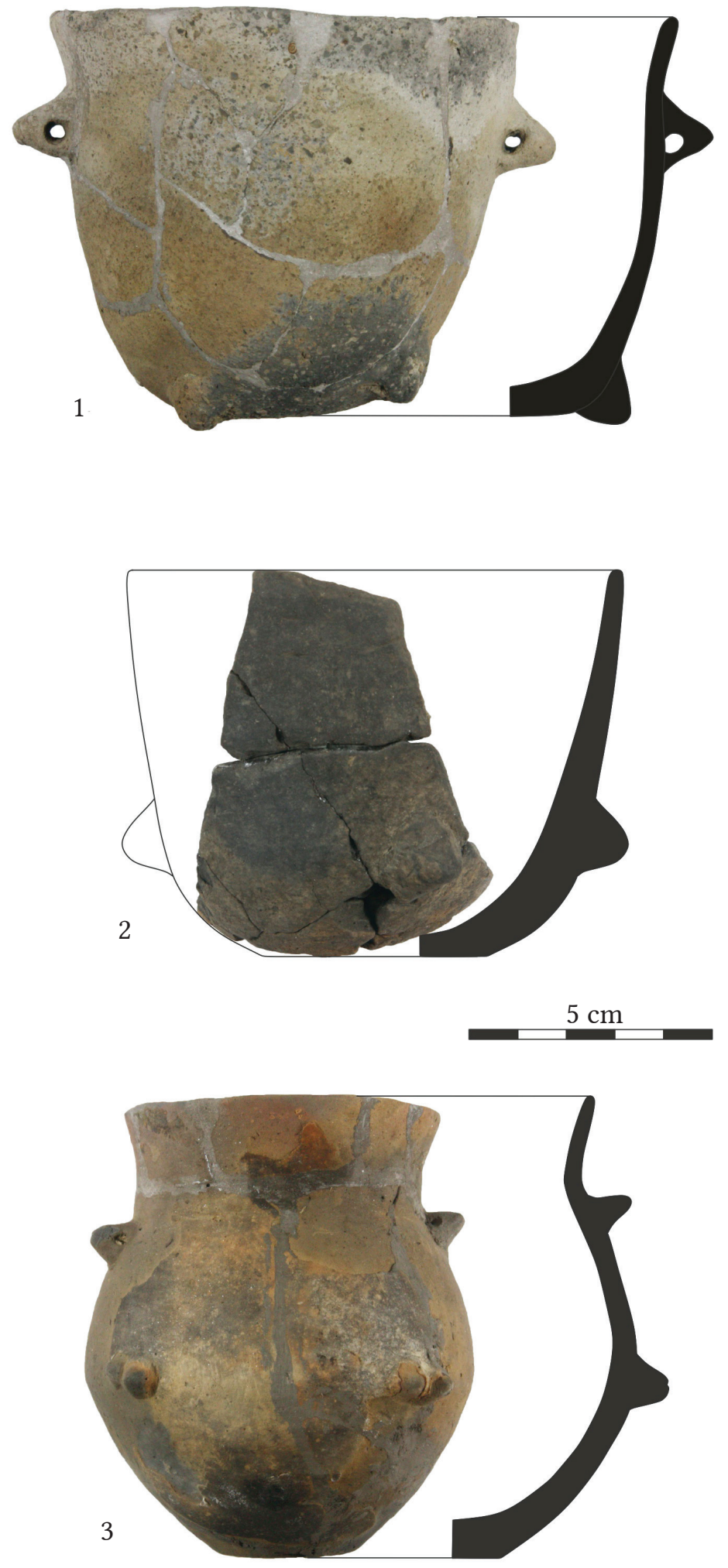

Fig. 13. Grave 38: 1 - tumbler, 2 - tumbler, 3 - jar. 

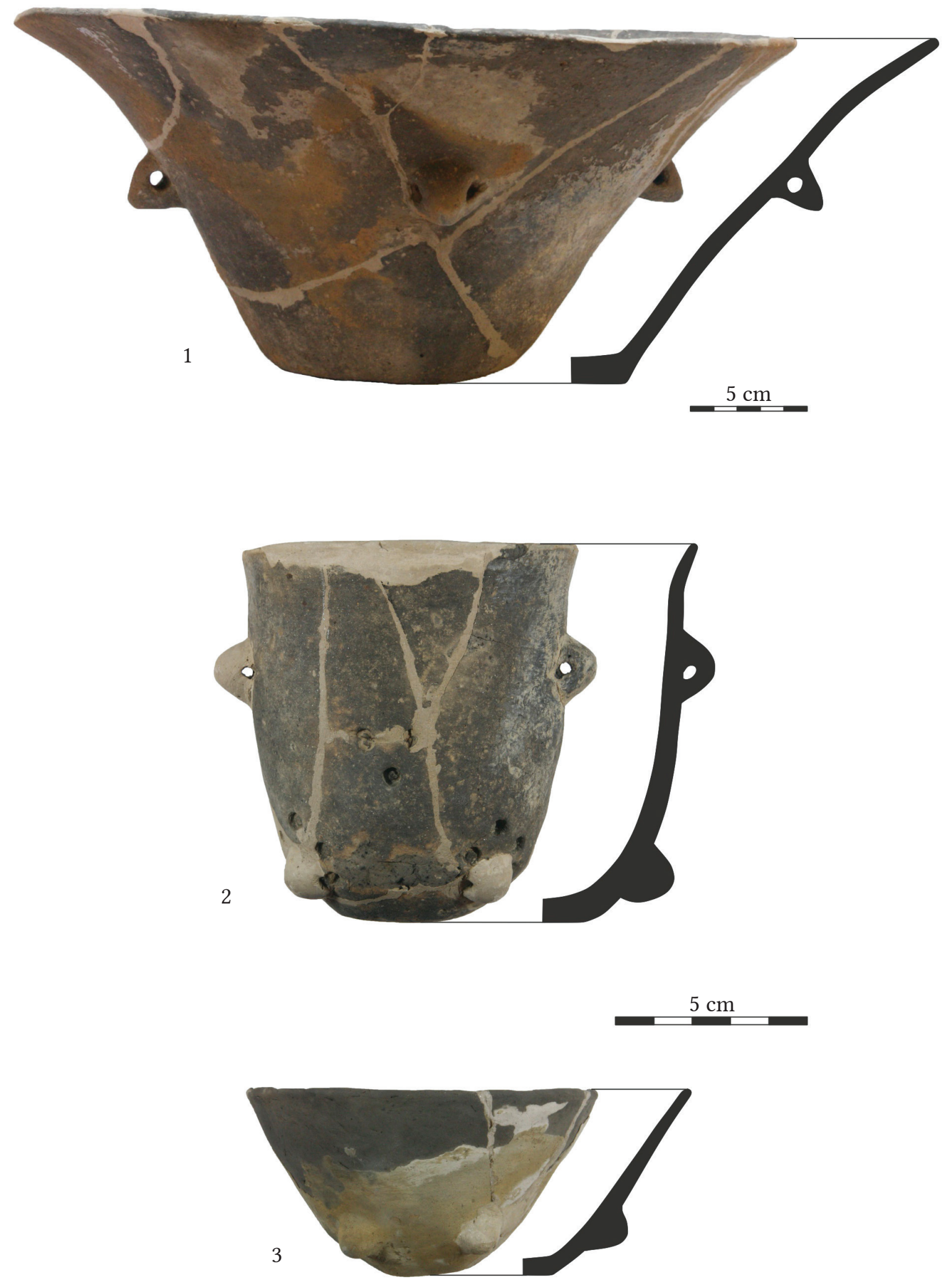

Fig. 14. Grave 38: 1 - bowl, 2 - tumbler, 3 - cup. 

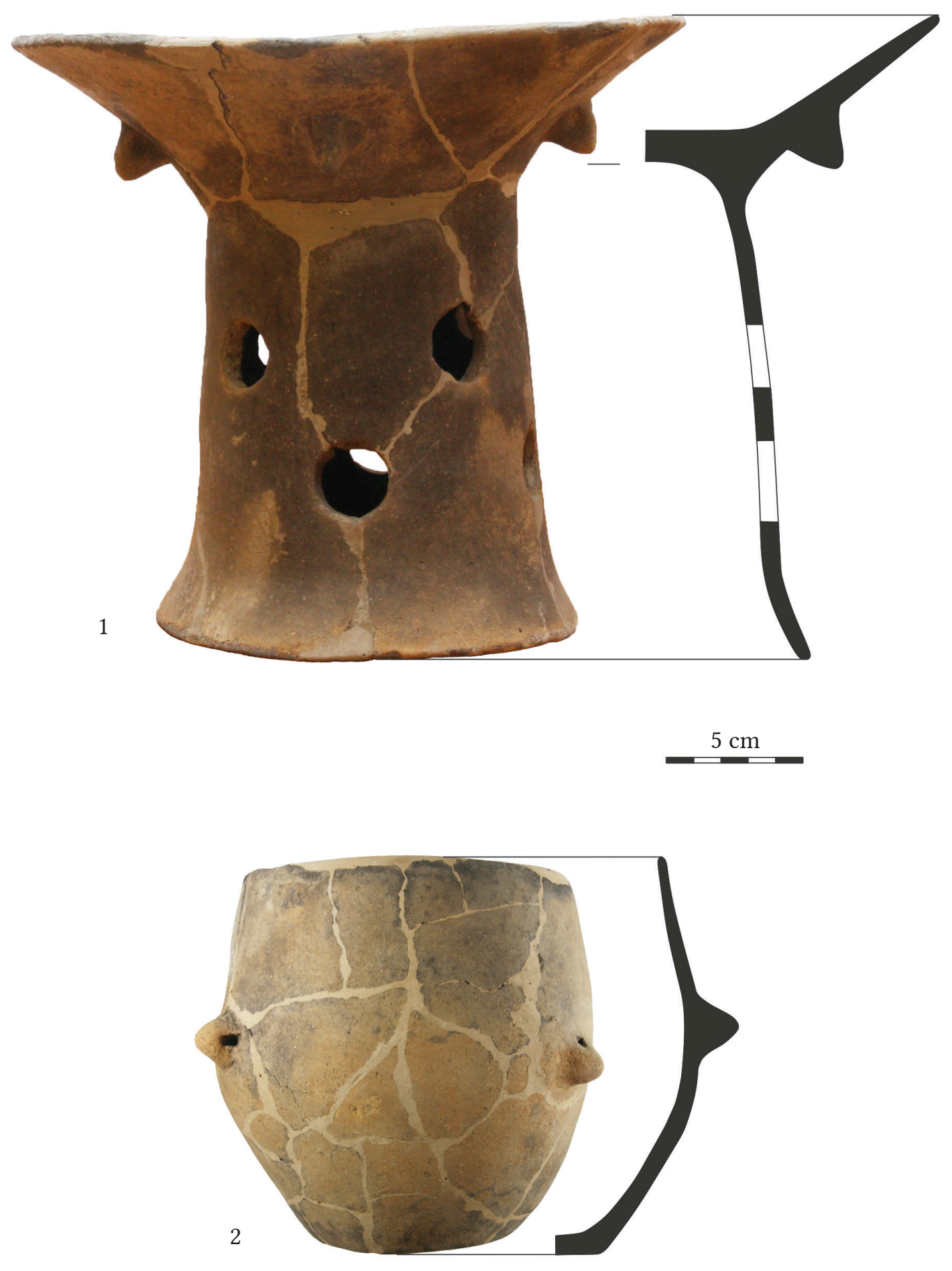

Fig. 15. Grave 38: 1 - hollow-pedestalled bowl, 2 - flowerpot-like vase. 


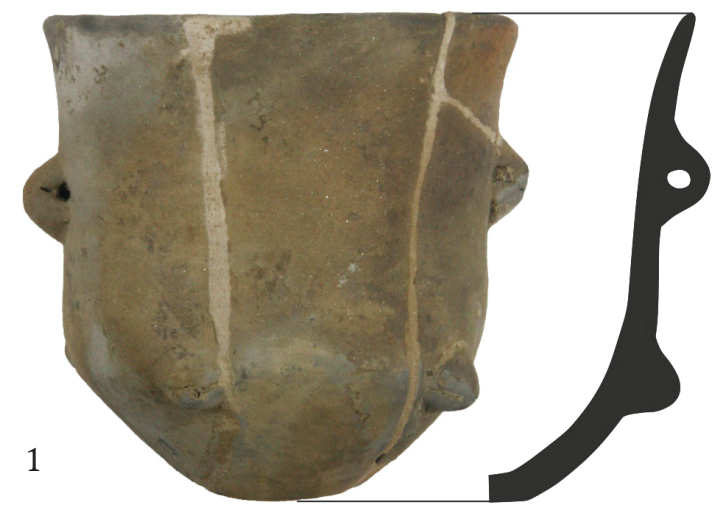

$5 \mathrm{~cm}$

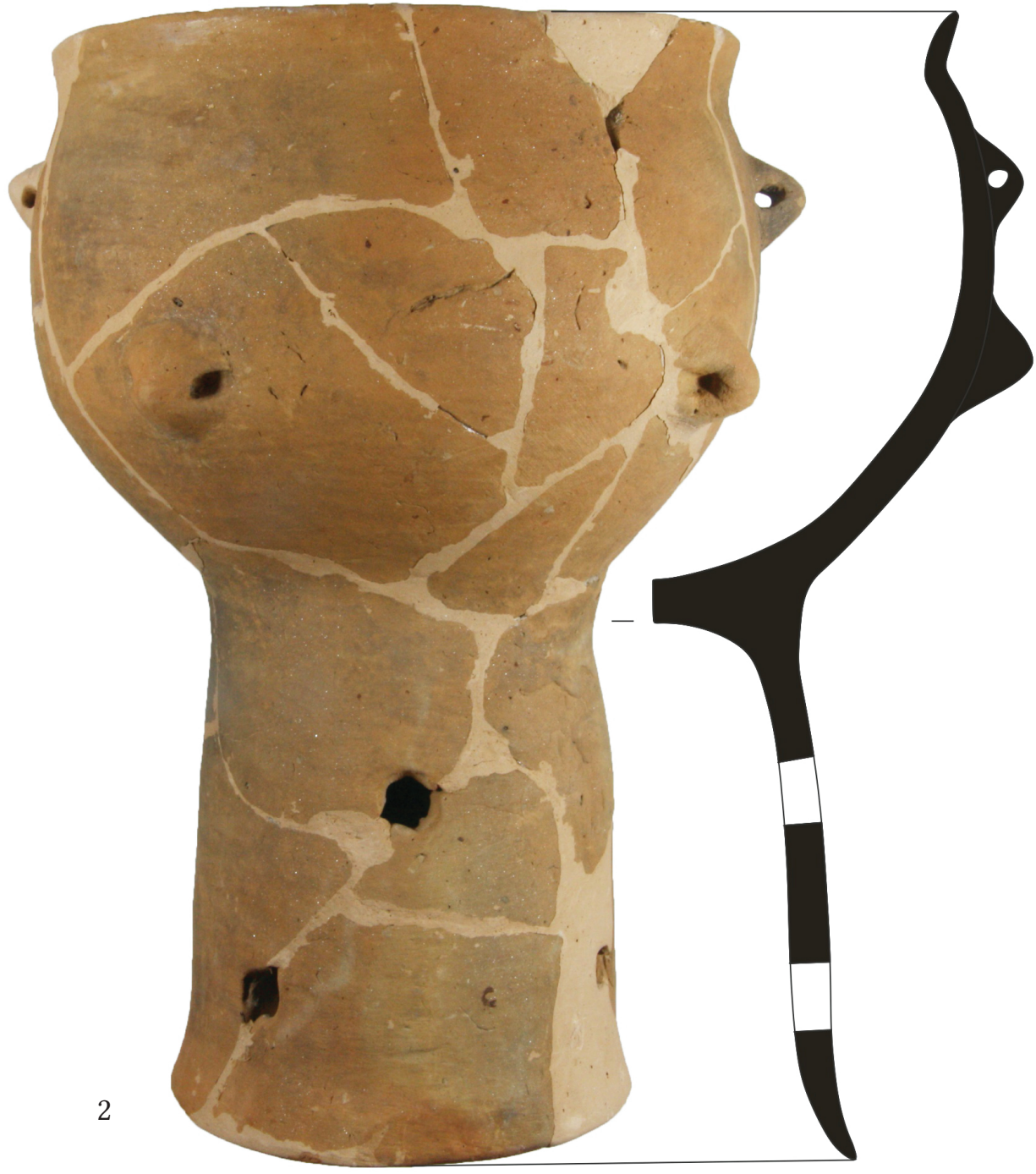

Fig. 16. Grave 38: 1 - tumbler, 2 - hollow-pedestalled goblet. 

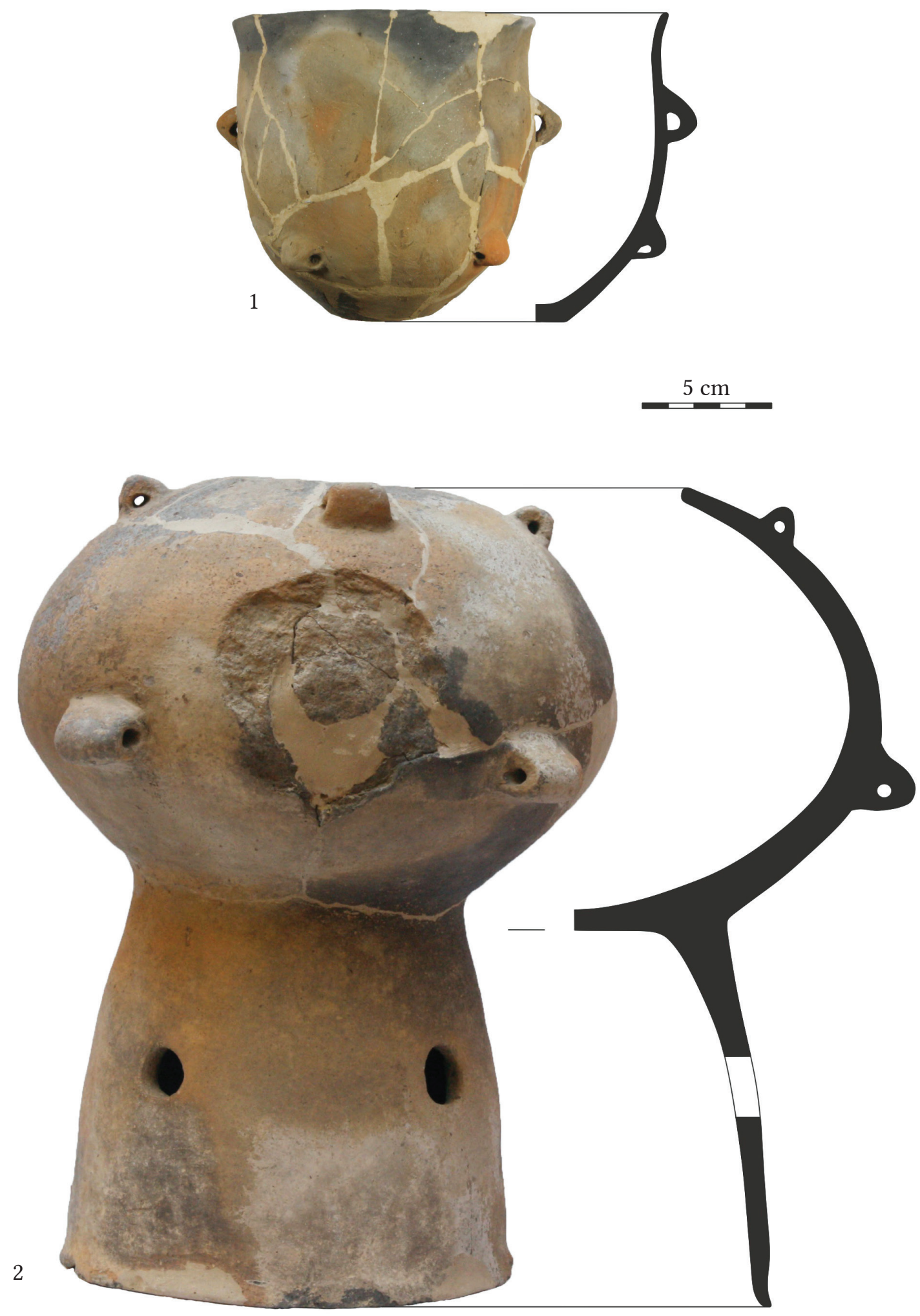

Fig. 17. Grave 38: 1 - jar, 2 - hollow-pedestalled globular vessel. 


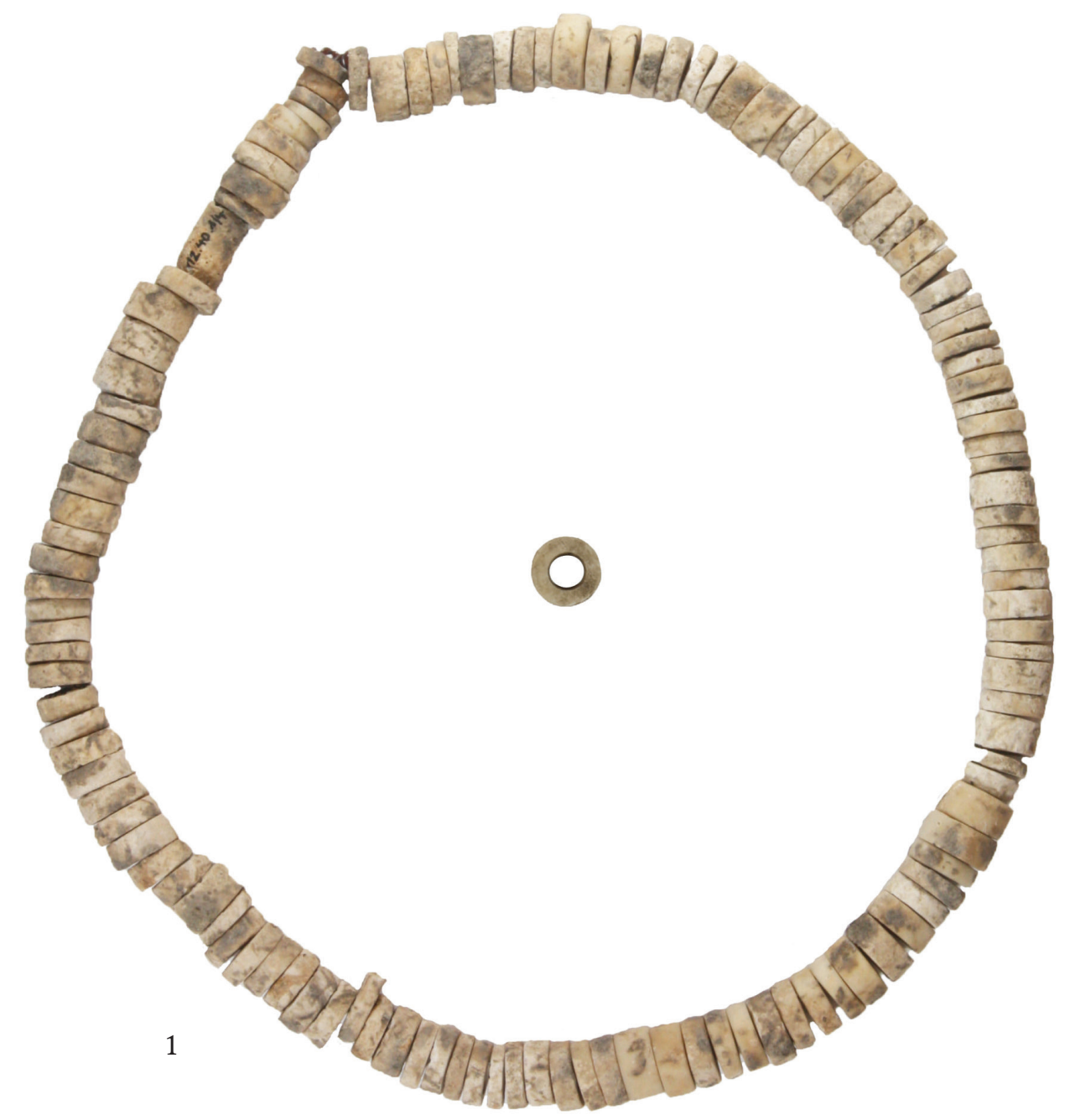

\section{$\infty$}

Fig. 18. Grave 38: 1 - beads, 2 - beads. 


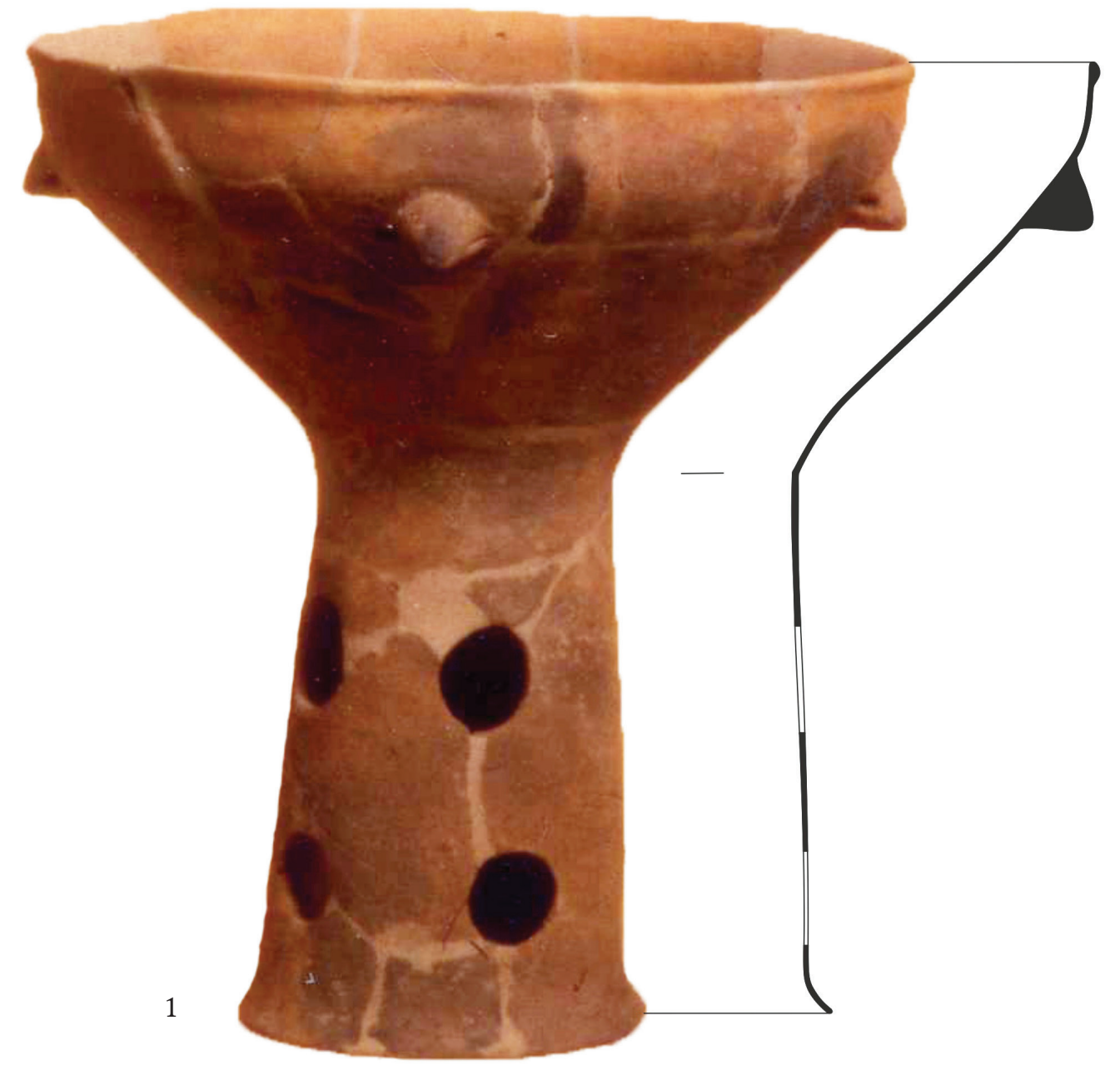

$5 \mathrm{~cm}$

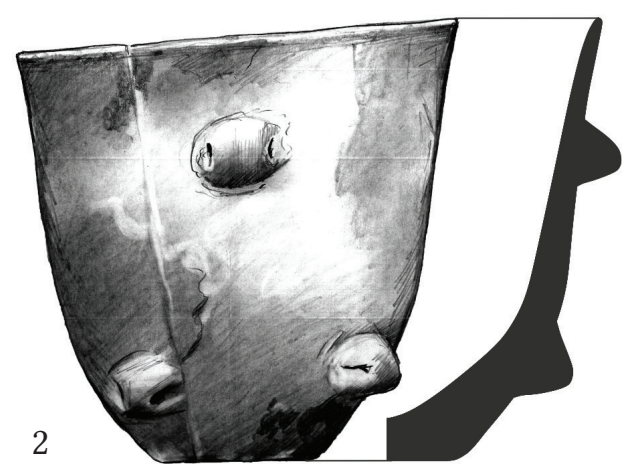

Fig. 19. Grave 39: 1 - hollow-pedestalled bowl, 2 - tumbler (The drawing was made by Katalin Nagy). 

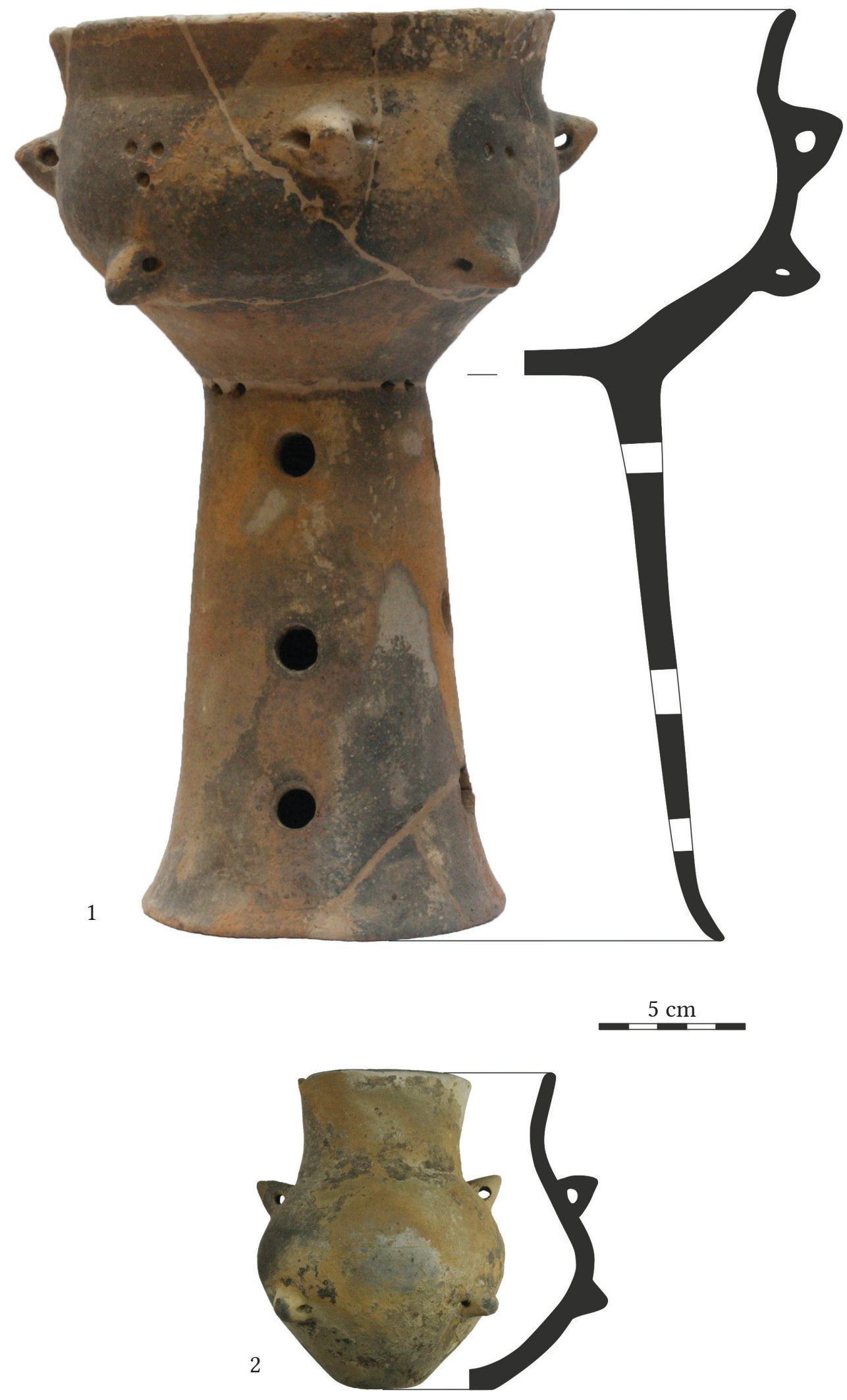

Fig. 20. Grave 39: 1 - hollow-pedestalled goblet, 2 - jar. 

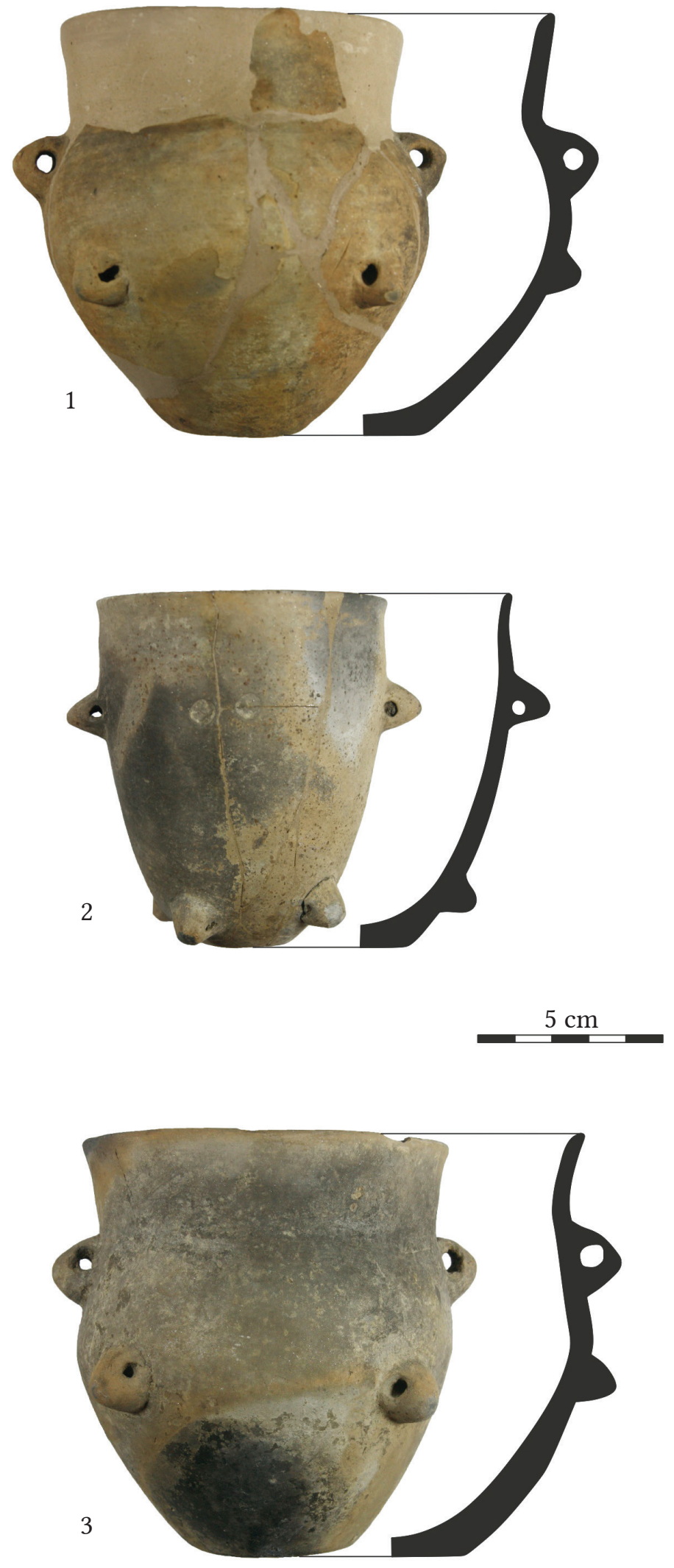

Fig. 21. Grave 39: 1 - jar, 2 - tumbler, 3 - jar. 

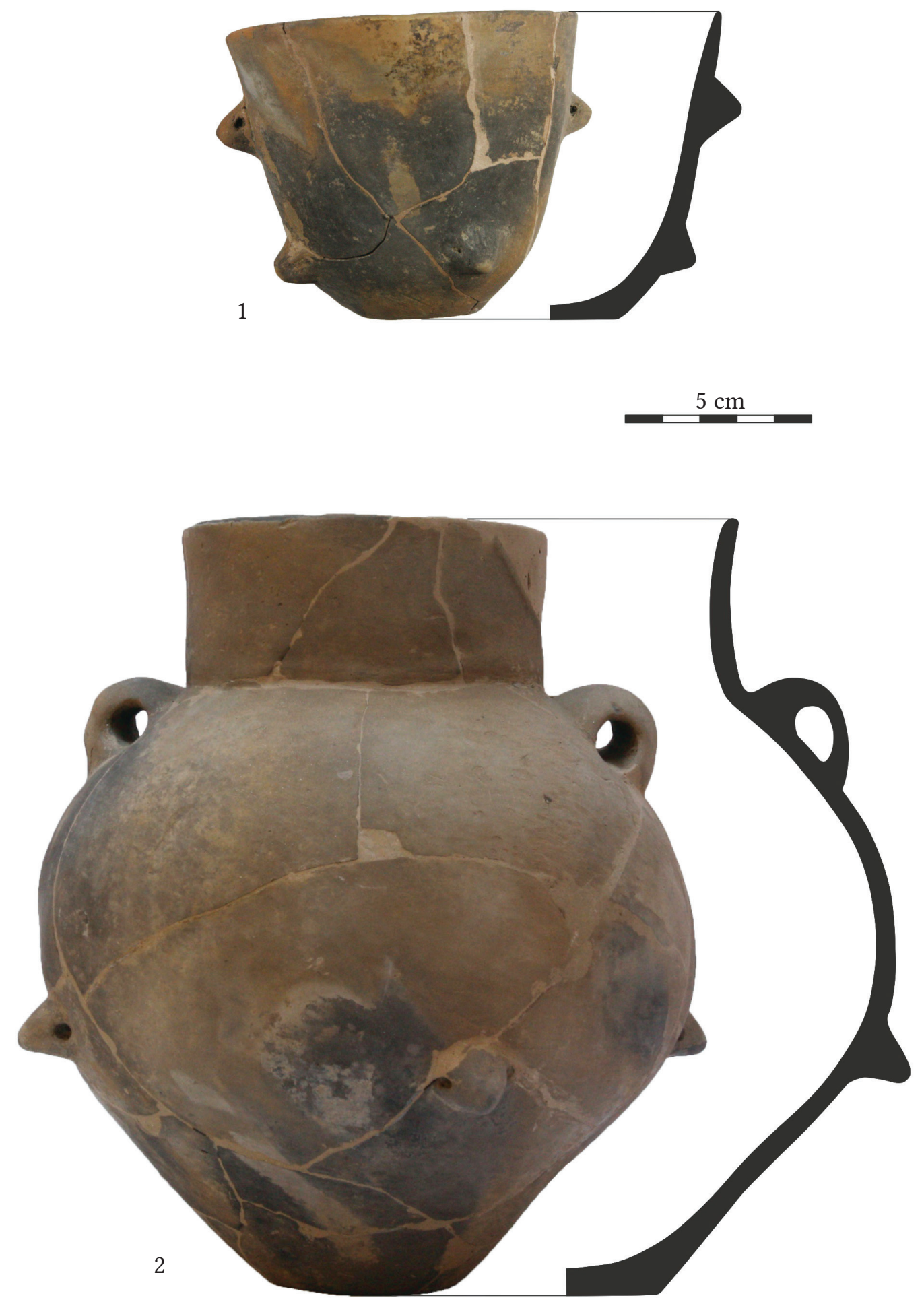

Fig. 22. Grave 39: 1 - tumbler, 2 - jar. 

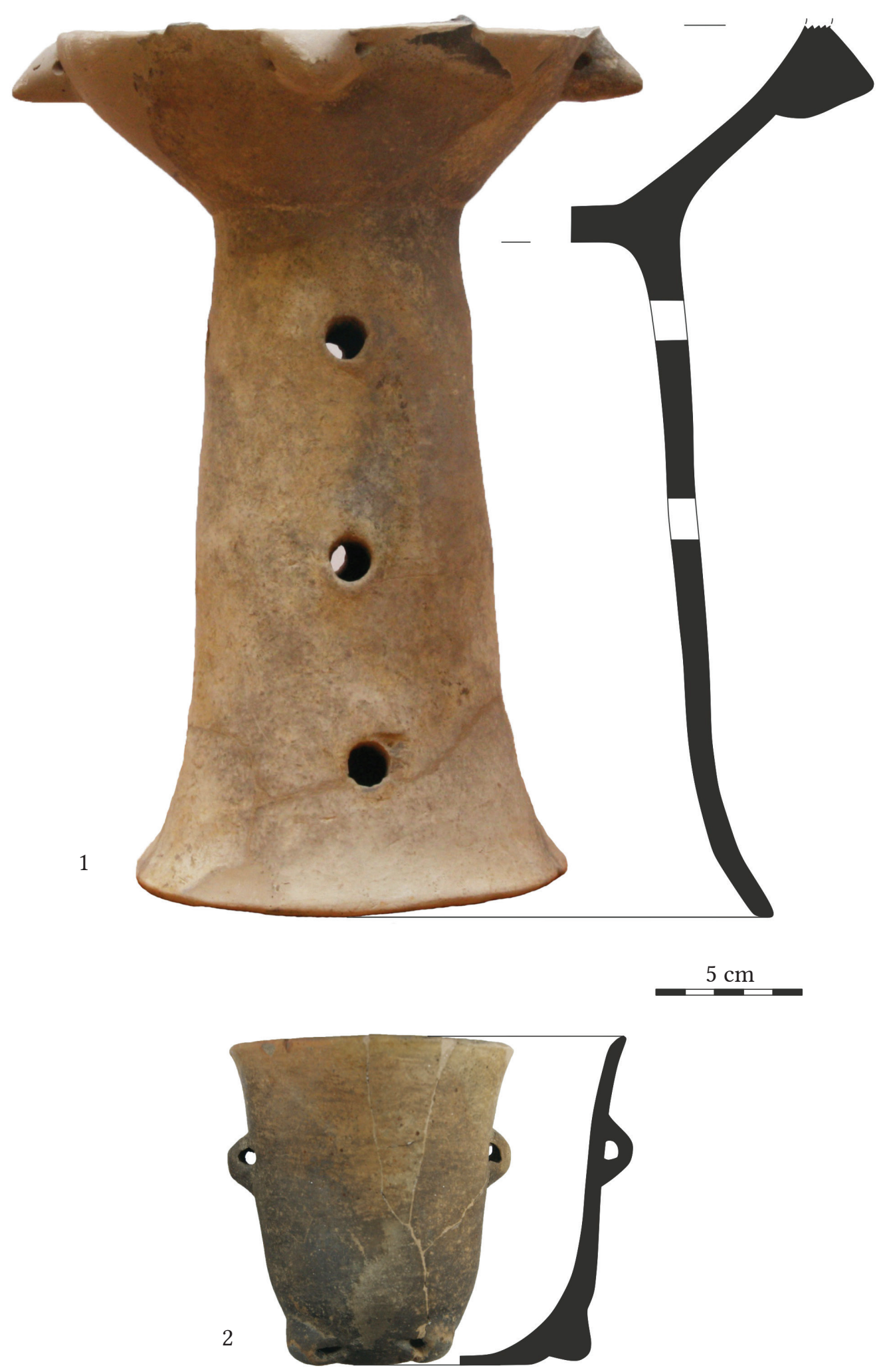

Fig. 23. Grave 39: 1 - hollow-pedestalled vessel, 2 - tumbler. 

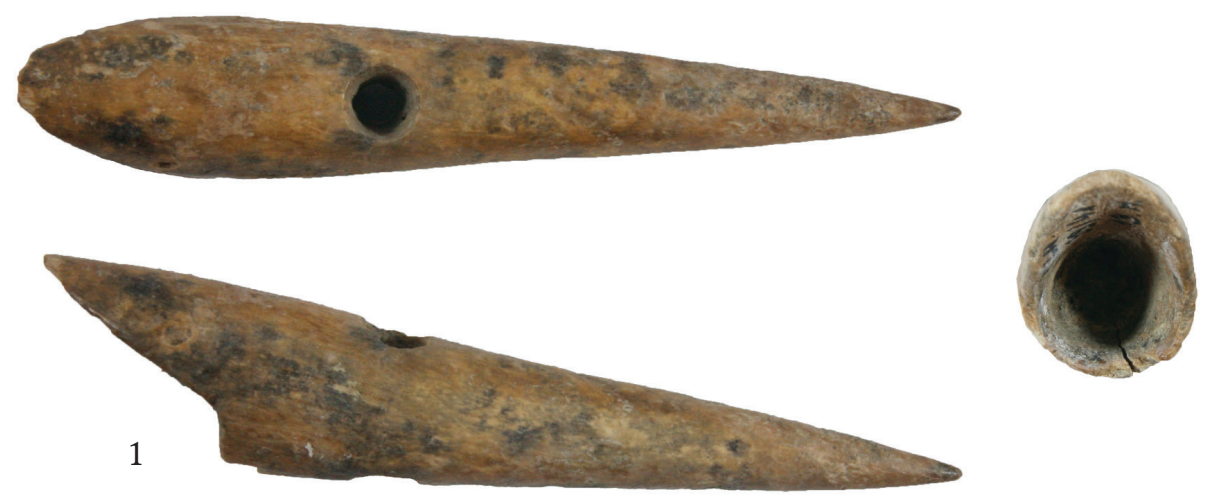

$5 \mathrm{~cm}$

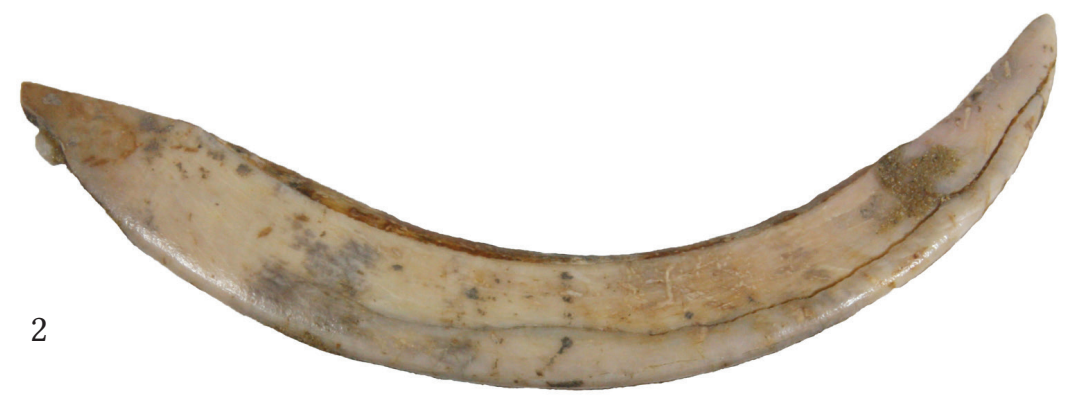

Fig. 24. Grave 39: 1 - antler, 2 - wild boar tusk. 

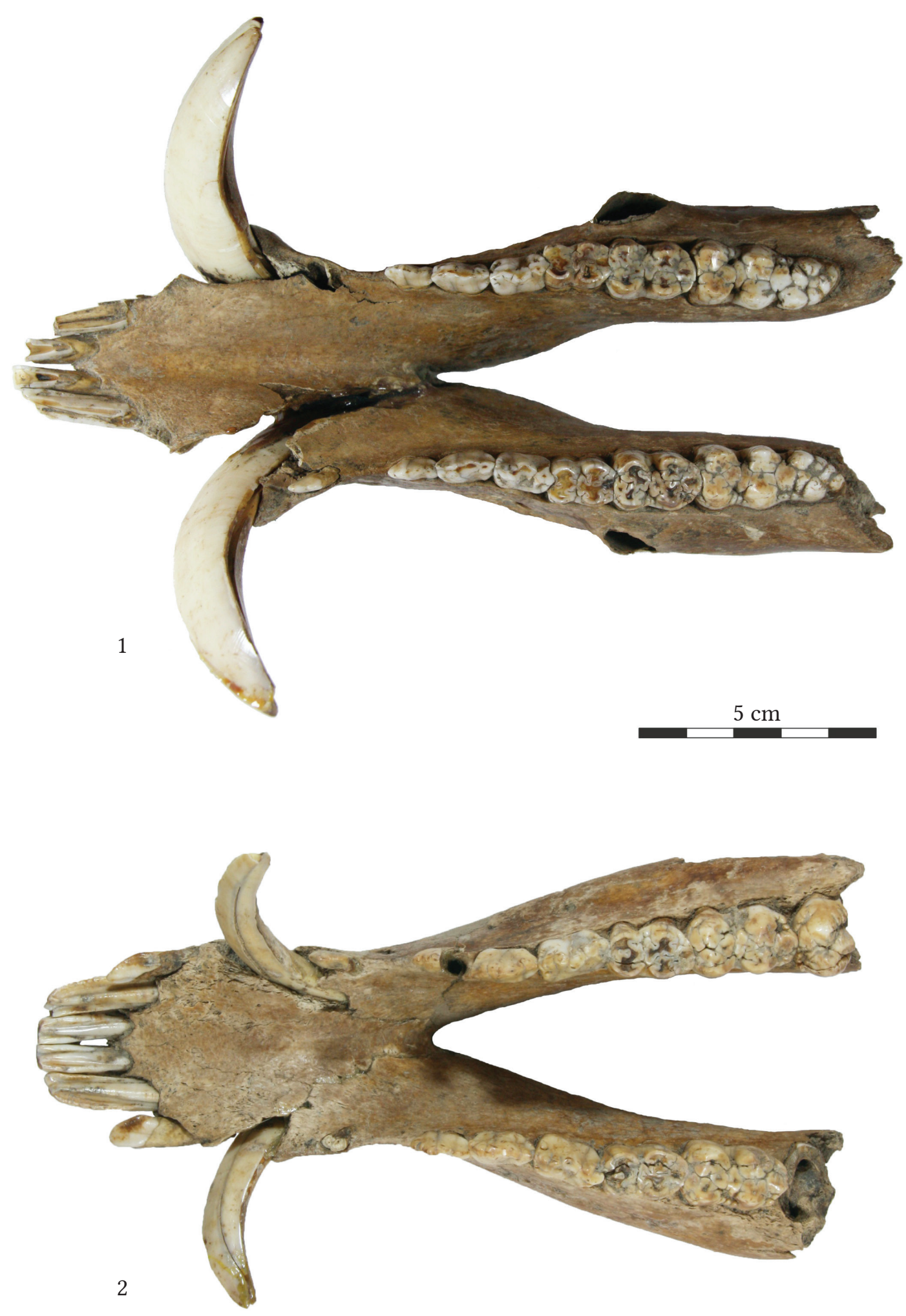

Fig. 25. Grave 39: 1 - swine's mandible, 2 - domestic pig's mandible. 

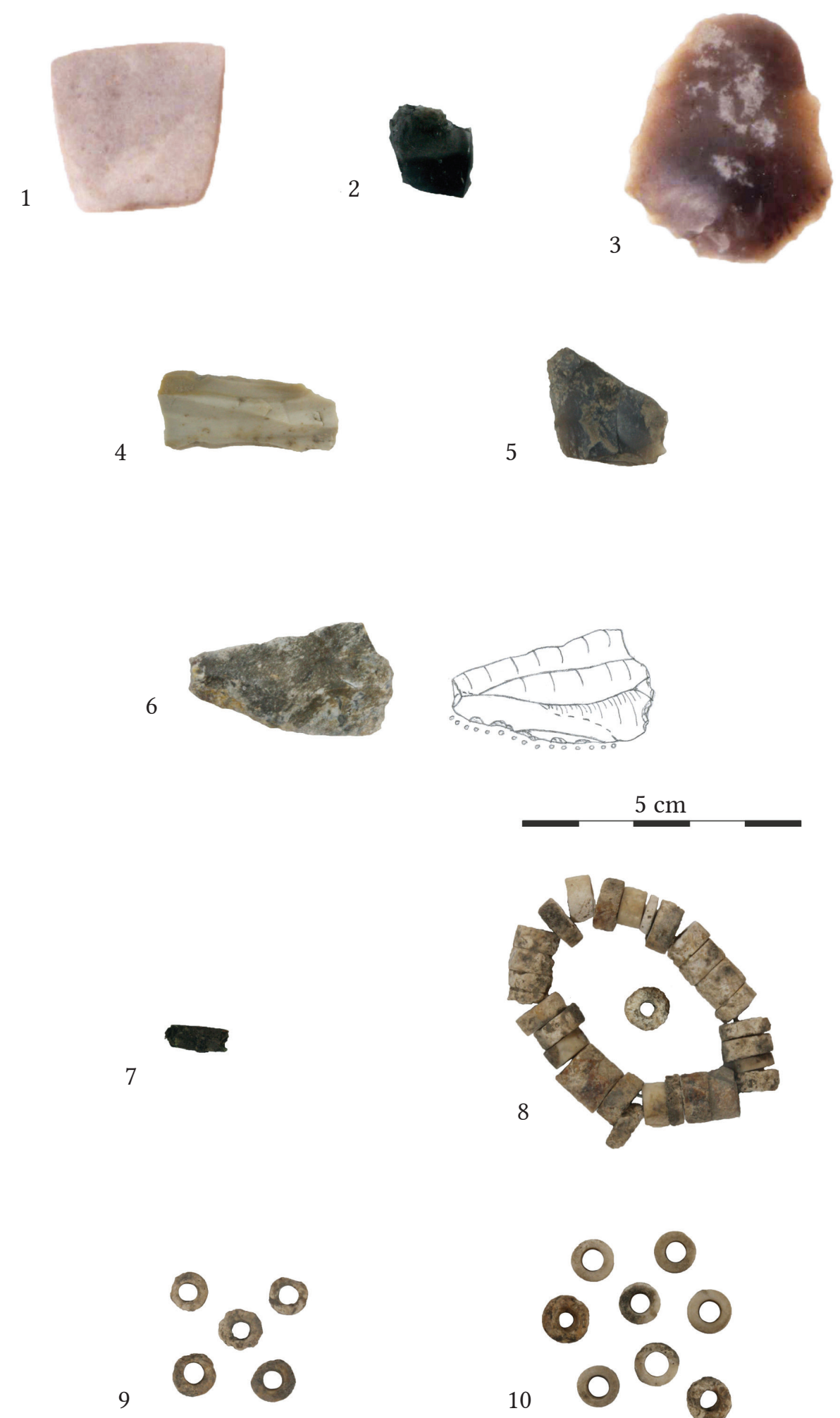

$5 \mathrm{~cm}$
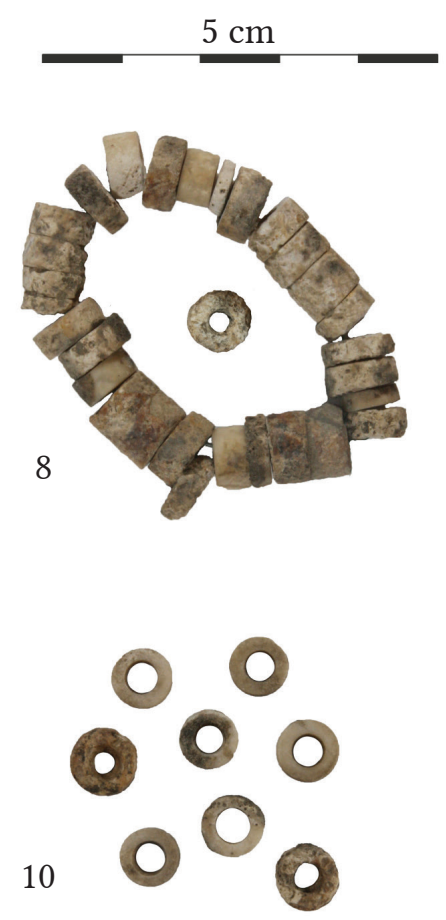

Fig. 26. Grave 39: 1 - chisel, 2 - chipped stone, 3 - chipped stone, 4 - chipped stone, 5 - chipped stone, 6 - chipped stone, 7 - copper bead, 8 - beads, 9 - beads, 10 - beads. 